\title{
Human leptin: from an adipocyte hormone to an endocrine mediator
}

\author{
Machteld Wauters, Robert V Considine ${ }^{1}$ and Luc F Van Gaal
}

Department of Endocrinology, Metabolism and Clinical Nutrition, University Hospital Antwerp, Wilrijkstraat 10, 2650 Edegem, Antwerp, Belgium and ${ }^{1}$ Division of Endocrinology and Metabolism, Indiana University School of Medicine, Clinical Building 459, 541 N Clinical Drive, Indianapolis, Indiana 46202-5111, USA

(Correspondence should be addressed to LVan Gaal; Email: luc.van.gaal@uza.uia.ac.be)

\begin{abstract}
Leptin is a mainly adipocyte-secreted protein that was discovered 5 years ago. Most of the research following this discovery focused on the role of leptin in body weight regulation, aiming to illuminate the pathophysiology of human obesity. However, more and more data are emerging that leptin is not only important in the regulation of food intake and energy balance, but that it also has a function as a metabolic and neuroendocrine hormone. It is now clear that it is especially involved in glucose metabolism, as well as in normal sexual maturation and reproduction. Besides this, interactions with the hypothalamic-pituitary-adrenal, thyroid and GH axes and even with haematopoiesis and the immune system have also been described. It has been shown that leptin secretion by the adipocyte is partly regulated by other hormones, such as insulin, cortisol, and sex steroids, mainly testosterone. Also, other hormones like thyroid hormone and GH are possibly involved in leptin synthesis. Leptin itself exerts effects on different endocrine axes, mainly on the hypothalamic-pituitary-gonadal axis and on insulin metabolism, but also on the hypothalamic-pituitary-adrenal, thyroid and GH axes.

Leptin may thus be considered a new endocrine mediator, besides its obvious role in body weight regulation.
\end{abstract}

European Journal of Endocrinology 143 293-311

\section{Introduction}

Leptin is a mainly adipocyte-secreted protein that was discovered only 5 years ago. In December 1994, Friedman's group reported the cloning of the obese $(o b)$ gene, responsible for the typical phenotype of obesity, diabetes and insulin resistance in $o b / o b$ mice (1). They also identified the human homologue gene, which showed a highly conserved sequence, being $84 \%$ identical with the mouse protein (1). Shortly afterwards, the protein product of this gene was identified and an assay for its detection in plasma developed (2). This $o b$ gene product was called 'leptin', derived from the Greek 'leptos' meaning 'lean', which indicates the function that this $o b$ gene product was thought to have. Most of the research following this discovery thus focused on the role of leptin in body weight regulation, aiming to illuminate the pathophysiology of human obesity.

However, more and more data are emerging that leptin is not only important in the regulation of food intake and energy balance, but that it also has a function as a metabolic and neuroendocrine hormone. It is especially involved in glucose metabolism, as well as in normal sexual maturation and reproduction, but also interacts with the hypothalamic-pituitary-adrenal, thyroid and growth hormone (GH) axes and even with haematopoiesis and the immune system. This review will focus in particular on these other functions, after highlighting the main issues concerning its role in body weight regulation.

\section{Leptin: a neuroendocrine regulator of energy balance}

The first function described after the discovery of leptin was its role in body weight regulation. Meanwhile it is clear that leptin plays an important role in this respect, especially in the regulation of body fat stores.

Leptin is synthesized mainly by fat cells, and its plasma levels in humans are strongly correlated with body mass index (BMI) and fat mass $(2-5)$.

The first rodent data on the $o b$ gene product fitted nicely in a lipostat model, as was proposed by Kennedy in the 1950s (6), and confirmed the hypothesis made in the 1970s by Coleman on the basis of his findings in parabiosis experiments (7). Leptin turned out to be the long-sought key molecule in these models for energy 


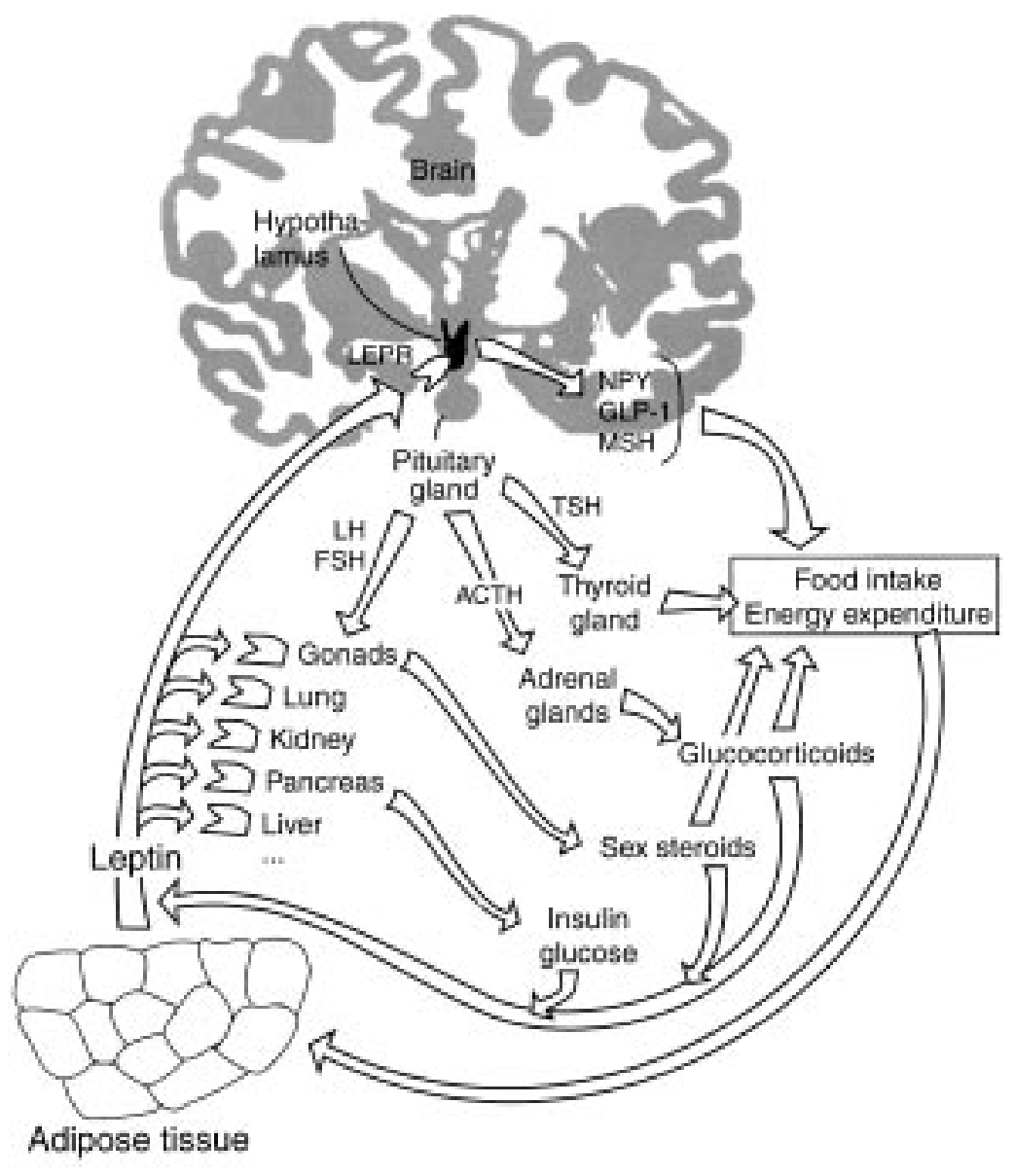

Figure 1 Schematic representation of central and peripheral actions of leptin on body weight regulation and on metabolic and endocrine parameters. Leptin secretion by fat cells is influenced by nutritional status, insulin, glucocorticoids and sex steroids. The leptin receptor in the brain is mainly present in the hypothalamus and choroid plexus, where food intake is regulated through modulation of several neurotransmitter pathways such as NPY, GLP-1 and $\mathrm{MSH}$. Leptin could also possibly modulate pituitary secretion of TSH, ACTH and gonadotrophins, thus influencing indirectly the secretion of $T_{3} / T_{4}$, cortisol and sex hormones respectively, which all also have effects on the energy balance. The leptin receptor is also widely distributed throughout peripheral tissues such as lung, liver, kidneys, pancreas and gonadal tissue, where leptin interacts with the production and secretion of, for example, insulin and sex steroids, which in turn influence leptin secretion by fat cells, thus creating a feedback system. balance regulation. It is secreted by adipocytes into the bloodstream $(4,8)$, and could thus be the signalling factor in a feedback system to the brain, informing the brain about the amount of fat mass in the body (Fig. 1). This hypothesis was confirmed by experiments with leptin injections to leptin-deficient $o b / o b$ mice, which led to weight loss by decreased food intake and increased energy expenditure (9-11). In normal mice as well, leptin administration reduced food intake and induced loss of fat mass, though less than in $o b / o b$ mice $(9-11)$.

Leptin receptors were cloned and identified in the choroid plexus and hypothalamus, a region known to be involved in the regulation of appetite, food intake and body weight $(12,13)$. More recently, the pathways through which leptin exerts its central nervous effects have also become more clear. From what is known at this moment, leptin seems to interact in the brain with almost all neuropeptides known to be involved in the regulation of energy balance and especially food intake (reviewed in ref. 14). Leptin inhibits neuropeptide Y (NPY) secretion (15) and raises corticotrophin-releasing hormone $(\mathrm{CRH})$ expression in the paraventricular nucleus (PVN) (13). Other pathways involved in the leptin response are the glucagon-like peptide-1 (GLP-1) system, the pro-opiomelanocortin (POMC) system, the neurons expressing orexins or hypocretins, CART (cocaine- and amphetamine-regulated transcript), and galanin (14).

After the cloning of the $o b$ gene, and when it was shown that a mutation in the gene was responsible for the $o b / o b$ phenotype in mice, the question was raised whether human obesity could be caused by mutations in this gene. Molecular screenings showed that in most obese subjects the gene encoding for leptin is normal (16-20). At this moment, only two (both highly consanguineous) families with a mutation in the leptin gene are identified, with in total six homozygous subjects known with congenital leptin deficiency leptin (21-23). In all cases, severe early onset obesity was reported, with very low leptin levels despite the high fat mass, a marked hyperphagia due to impaired satiety, and hyperinsulinaemia. Treatment with recombinant methionyl human leptin resulted in sustained weight reduction and improvement of all these metabolic abnormalities (24). Family members who were heterozygous for the mutation were not morbidly obese, and their leptin levels were comparable to normal controls. 
These mutations however occur very rarely and, in general, human obesity cannot be explained by a defect in the leptin gene or deficient leptin secretion. On the contrary, in humans, leptin mRNA expression and serum leptin levels are much higher in obese individuals compared with lean subjects and correlate strongly with body fat $(2-5)$. From these data, the hypothesis of some kind of leptin insensitivity or leptin resistance in human obesity emerged, comparable to insulin resistance in type 2 diabetes $(4,25)$. Such a resistance could theoretically occur at several levels in the leptin signalling pathway (25). A first possible cause of leptin resistance could be a receptor defect, leading to failure to bind or activate the leptin receptor, as is seen in the diabetes $(d b / d b)$ mouse model and the fatty $(f a / f a)$ and Koletsky rat. In humans however, such a defect seems to be very rare $(26,27)$. At this moment, only one mutation in the human leptin receptor gene resulting in a truncated leptin receptor lacking the transmembrane and intracellular domain was reported (28). The production of a non-functional receptor induces a phenotype with early onset, morbid obesity, developing within the first months of life, hyperphagia, no pubertal development and an impaired secretion of $\mathrm{GH}$ and thyrotrophin. Leptin levels were extremely high: between 500 and $700 \mathrm{ng} / \mathrm{ml}$ in the homozygotes and between 145 and $362 \mathrm{ng} / \mathrm{ml}$ in heterozygous family members (28). But as is the case with the mutation in the $o b$ gene, this defect seems to be very exceptional and can certainly not account for the current high prevalences of overweight and obesity. Several polymorphisms in the leptin receptor (LEPR) gene have been identified $(26,27,29-33)$, which could possibly evolve in changes in binding or signalling activity of the receptors. However, until now, none of the studies on these LEPR polymorphisms were able to show a major effect on body weight or fat mass $(26,27$, $31-38)$.

A second possible mechanism of leptin resistance could be an imbalance in the blood between leptin and its binding protein. If the proportion of leptin bound in the blood is too high, this can decrease the biological activity of the hormone. It was shown that in humans the ratio of bound to free leptin in the blood is different in lean and obese subjects, the proportion of free leptin being positively correlated with BMI (39).

Also an impaired transport of leptin into the central nervous system through the blood-brain barrier can lead to leptin resistance. This transport is known to be a specific and saturable mechanism (40-42), possibly mediated through a short form of the leptin receptor, present in high density in the choroid plexus $(12,41)$. A rodent model for such a form of leptin resistance, due to a decreased transport into the cerebrospinal fluid (CSF), is the New Zealand Obese (NZO) mouse, which does not respond to peripheral leptin, but is normally responsive to leptin when it is administered i.c.v. (43). In humans it was shown that the ratio of leptin in cerebrospinal fluid to serum leptin is decreased in obesity $(41,42)$. So differences in the access of leptin to the CSF could be important in the pathogenesis of some forms of obesity, if part of the serum leptin is not able to reach its site of action, thereby not raising central leptin concentrations as high as peripheral.

Finally, leptin resistance could be caused by a postreceptor defect leading to a failure to activate the abovementioned neuroendocrine mediators. At this moment, these pathways are not yet fully understood, but there is much ongoing research on these particular pathways and their interactions (reviewed in ref. 44). Elucidation of these post-receptor pathways in the brain will contribute to explaining the central working mechanisms of leptin.

\section{Leptin during sexual development and reproduction}

\section{Gender differences in leptin levels}

From the first reports of leptin measurements in humans, it was already evident that a clear gender difference in leptin levels existed: leptin levels were found to be two- to threefold higher in women than in men for the same BMI $(2,5)$. These differences reflect the difference in body composition between men and women, women in general having a higher percentage of body fat and a higher ratio of subcutaneous to visceral fat. Serum leptin is strongly related to fat mass, and even stronger to subcutaneous fat (45-47), which has been shown to secrete more leptin (48-50). Thus, the higher fat mass in women, and in particular the presence of more subcutaneous fat, could reasonably explain the higher leptin levels. However, even after correcting or matching for BMI $(41,51,52)$, fat mass $(47,53-55)$, or for the amount of subcutaneous fat (47), the difference in leptin levels remains significant. This difference has already been observed in children, with leptin levels in girls always being higher than in boys, even at birth, when measured in cord blood (56-58), but especially from puberty onwards (59-64).

In vitro data show that leptin secretion by adipose tissue from men and women is different, with a significantly higher spontaneous secretion by adipocytes from women than from men (65) and a higher ratio of subcutaneous-to-omental leptin mRNA expression in women (49). Furthermore it was shown that women have also higher cerebrospinal leptin levels, even for a given plasma level, probably due to increased leptin transport into the CSF (41).

These observations suggest that other factors besides adiposity, such as sex steroids, might play a role in this gender difference. This is confirmed by in vitro experiments and by human data.

Oestrogens were shown to stimulate leptin secretion by adipocytes in vitro $(66,67)$, an effect which is observed only in adipocytes from women and not in samples from men (64). Leptin levels are decreased in ovariectomized 
rats, and reversed to normal by oestradiol supplementation $(67,68)$. In humans, exogenous follicle-stimulating hormone (FSH) administration during an IVF program increased leptin levels, together with oestrogen $(69,70)$. In children, oestrogen could explain up to $5 \%$ of the variance in leptin concentrations (62).

Androgens, on the other hand, have an inhibitory effect on leptin secretion. Testosterone suppresses leptin mRNA expression and secretion by human adipose cells (63). Testosterone administration to rats decreased expression of leptin mRNA, but did not change circulating leptin levels (71). Anabolic androgenic steroid use by male bodybuilders reduced leptin levels significantly (72), whereas suppression of testosterone production by gonadotrophin releasing hormone $(\mathrm{GnRH})$ agonist administration in these bodybuilders or in boys with precocious puberty increased leptin levels $(72,73)$. Hypogonadal men show elevated leptin levels (74), which are reduced by testosterone substitution (75). Cross-sex hormones in male-to-female and female-tomale transsexuals induced a reversal of the sexual dimorphism in serum leptin levels over 4 months, independent of the amount of body fat (76). Leptin and testosterone levels are inversely correlated in men and boys $(59,63,74,77,78)$. Testosterone could account for about $10 \%$ of the variation of leptin in a multiple regression model in young boys $(60,62,63)$. Thus, the suppressive effect of androgens can partly explain the gender differences in leptin levels, in addition to the differences in body composition and fat distribution.

\section{Role of leptin in pubertal development}

Puberty results from maturation of the hypothalamicpituitary-gonadal axis and the onset of it is closely related to an increase in GnRH activity, inducing release of gonadotrophins and secretion of sex steroid hormones (79). This activation of the hypothalamicpituitary-gonadal axis could be triggered by leptin. It has been known for more than 20 years that in girls a minimum cut-off weight or 'critical fat mass' is necessary to attain menarche and to avoid or restore secondary amenorrhoea (80). Since leptin levels reflect the amount of body fat, being elevated in obese humans and low in anorectic subjects $(81,82)$ and in lean amenorrhoeic female athletes (83), leptin seems an excellent candidate to act as a signal to the hypothalamus whether adipose mass is adequate or insufficient for reproduction. This hypothesis is supported by a growing body of evidence, ranging from experiments in $o b / o b$ mice, to longitudinal observations in normal children during puberty.

Leptin acts centrally on the hypothalamic-pituitarygonadal axis, stimulating the release of FSH and luteinizing hormone (LH) from the pituitary gland in rats $(84,85)$. A recent study also showed co-localization of leptin with LH and FSH in human anterior pituitary cells, as well as altered FSH secretion by gonadotroph adenomas after incubation with leptin (86).
Leptin receptor isoforms, including the long signalling form of the receptor, are present in gonadal tissue, suggesting that leptin could exert a direct endocrine action on the gonads (87-89). In contrast to the central stimulating effect, the local effect of leptin seems to be inhibitory for steroid synthesis. In vitro studies showed that leptin can suppress ovarian production of oestradiol (89-91) and progesterone $(92,93)$, induced by LH and FSH, and by insulin or FSH and dexamethasone respectively. Leptin also increased slightly the insulininduced proliferation of thecal cells.

Thus, leptin exerts a central stimulatory effect on steroid secretion, through central stimulation of GnRH release, whereas the local effect seems inhibitory (Fig. 2). These data, resulting from different kinds of studies (in rodents in vivo vs in vitro studies), seem to be contradictory, and it is not clear which effect is predominant in vivo in humans.

Chehab and colleagues were the first to show that the sterility defect seen in female leptin deficient $o b / o b$ mice, which is caused by an insufficiency of regulatory hormones at the hypothalamic-pituitary level, can be completely corrected by leptin treatment, resulting in ovulation, pregnancy and parturition (94). Also in male $o b / o b$ mice, reproductive ability could be restored by leptin treatment (95). Leptin injections elevated levels of $\mathrm{LH}$ in female and of FSH in male $o b / o b$ mice, and stimulated gonadal development in both (96), while chronic administration of antileptin antibody has been shown to inhibit LH release in rats (97). In normal female mice, leptin peaks during the second post-natal week, independent of fat mass or food intake, preceding a rise in oestradiol to adult levels (98). Leptin injection accelerates the onset of puberty $(99,100)$, probably by triggering the pulsatile release of GnRH. In normal mice who were partially starved, leptin treatment normalized levels of circulating gonadotrophins (LH) and sex steroids, thereby limiting the delay in pubertal maturation compared with pair-fed mice without leptin treatment $(101,102)$. These different rodent studies do not only show that leptin plays a role in the physiology of puberty and reproduction, but also that these effects are not secondary to the effects on energy balance or fat accumulation.

Leptin deficiency in humans offers an interesting model providing information about what happens in the absence of leptin. Two adult patients homozygous for the leptin mutation are known at the moment: a female patient showed primary amenorrhoea at age 34 , while a man aged 22 was still pre-pubertal, with clinical traits typical for hypogonadism and androgen deficit (22). The younger subjects with leptin receptor deficiency showed no pubertal development at the age of 13 and 19 (28). This shows that a normal leptin function is essential for the onset of puberty in humans, as was already shown in rodents.

The mechanism is not clear yet, but is probably of hypothalamic origin, since administration of GnRH to 


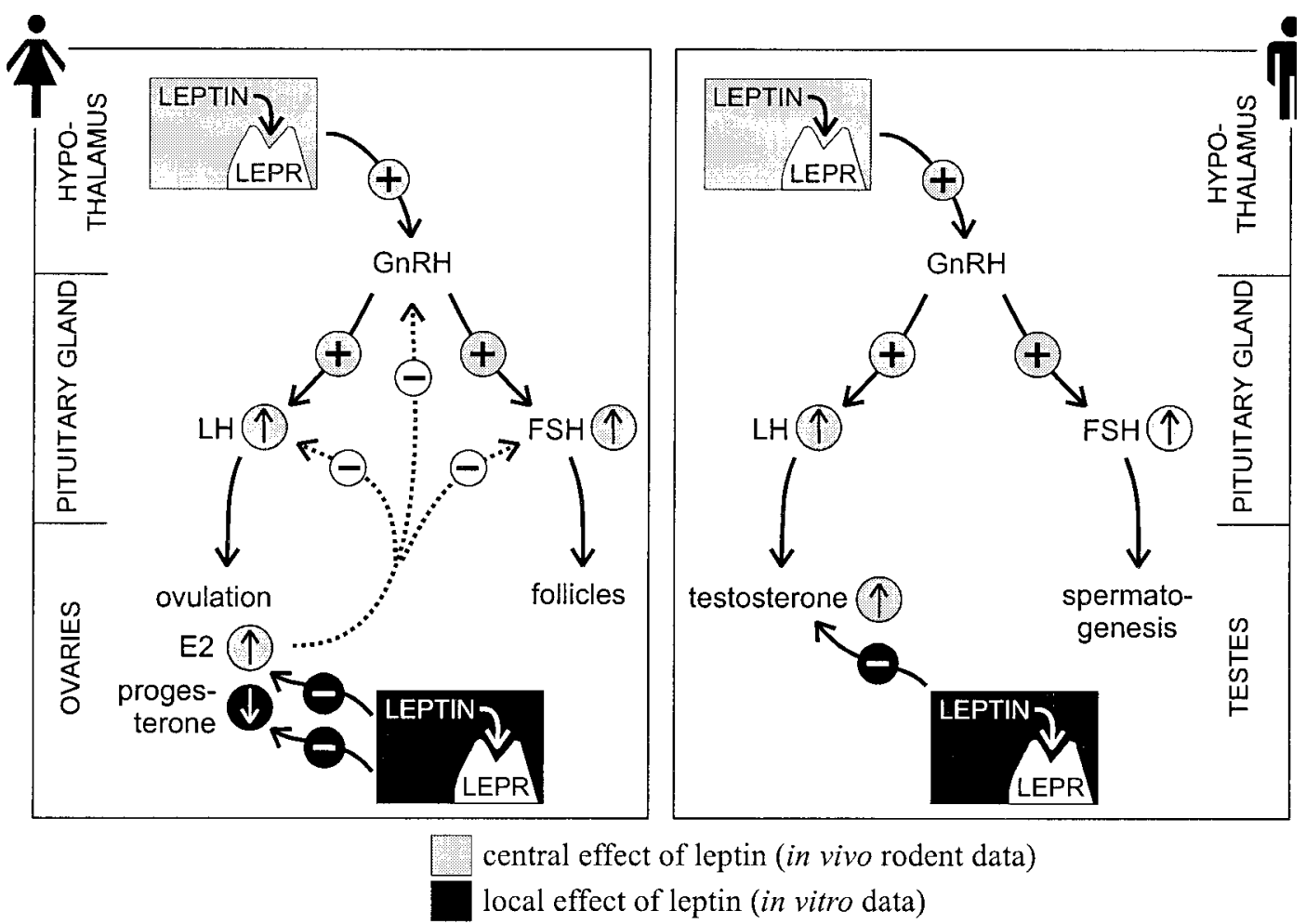

Figure 2 Effects of leptin on the hypothalamic-pituitary-gonadal axis: central stimulatory effect on oestradiol and testosterone production through stimulation of $\mathrm{GnRH}, \mathrm{LH}$ and FSH secretion (data from in vivo studies in rodents). Direct peripheral inhibitory effect on progesterone and testosterone through the leptin receptor which is present on ovaries and testes (data from in vitro studies).

the leptin-deficient man induced a normal increase of $\mathrm{LH}$ and $\mathrm{FSH}$, and administration of gonadotrophin increased testosterone levels (22). Leptin could act directly by stimulating the secretion of GnRH by hypothalamic neurons, or the secretion of gonadotrophins by the pituitary gland (84), or indirectly by sensitizing the hypothalamus through increased leptin pulsatility (103).

During normal puberty, girls increase the amount of percentage of body fat, a mechanism regulated by sex hormones and GH. Leptin concentrations could also be involved in this process: leptin levels reflect total adipose tissue, and are highly correlated with subcutaneous fat. In young girls accumulation of (subcutaneous) body fat seems to be related in an almost parallel way to increasing levels of leptin during puberty $(59-61,64)$, followed by an increase in FSH and later in $\mathrm{LH}$ and oestradiol. At the same time, pulses in leptin secretion are higher in girls than in boys (104). This diurnal variation could be an important factor in the hypothalamic regulation of menstruation, since it was also shown that this normal variation is absent in amenorrhoeic longdistance runners (83) and patients with anorexia nervosa (105).

In young boys it was shown in a longitudinal study that the rise in testosterone levels at the onset of puberty is preceded by a peak in leptin levels (106), whereas after initiation of puberty, these dropped to pre-pubertal levels. This study confirmed cross-sectional data that showed an increase in leptin levels in boys only up to Tanner stage 2, and a decrease later in puberty (59-61). A similar evolution is seen for leptin binding activity, with high leptin binding activity in pre-pubertal years and a reduction of the binding leptin receptor through puberty, and this in boys and girls (107).

The differential evolution of leptin levels between boys and girls could partly be explained by the different evolution of body composition during puberty: whereas girls accumulate more fat mass, the increase in BMI in boys is mainly caused by an increase in muscle mass, especially during late puberty. Since leptin is mainly determined by fat mass, in particular by the amount of subcutaneous fat, this difference could explain part of the difference between boys and girls, though not all of it. The question remains open whether sex steroids play a role in this process.

\section{Leptin levels during the menstrual cycle}

Longitudinal studies have found a physiological fluctuation of leptin levels during the menstrual cycle, with lower circulating leptin levels in the early follicular phase, an increase in leptin in the luteal phase of the cycle, and a pre-ovulatory peak in leptin $(68,69,108-111)$. The 
changes in leptin are associated with changes in sex hormones, namely with progesterone $(108,110,111)$, oestrogens $(68,69,111)$ and LH $(112,113)$. It is important to be aware of this variation when studying leptin levels in women, in order to measure leptin at the same moment of the cycle. In women taking oral contraceptives, leptin levels remain unchanged throughout the cycle (111) but levels are not different from normally cycling females (114).

\section{Pregnancy}

Pregnancy is a period of dramatic changes in the body, with short-term weight gain, increased fat stores, new tissue synthesis and major hormonal and metabolic changes. During pregnancy, plasma leptin levels are elevated (115-118), rising especially during the second trimester $(66,108,119,120)$, and dropping sharply after delivery. This increase is correlated with gestational weight gain, and absolute leptin levels are correlated with BMI $(57,117-119)$. This hyperleptinaemia during pregnancy occurs with the appearance of a circulating form of the leptin receptor, functioning as a binding protein (121). It was shown in mice that the hyperleptinaemia of late pregnancy is attributable to binding of leptin by this placenta-secreted soluble form of the leptin receptor (122). Another factor contributing to the rise in leptin levels is the production of leptin by placenta and foetus, partly secreted into the maternal circulation $(57,123-124)$. In addition to this, changes occur in the levels of other hormones that may influence leptin. Insulin levels are increased during pregnancy, and also gestational hormones like human chorionic gonadotrophin and oestrogen can stimulate leptin production by adipocytes, at least in vitro (66). It is not clear whether leptin synthesized by placenta acts as a growth factor for the foetus or as a signal of energy status between mother and foetus. The leptin receptor is also expressed by the placenta, the long signalling form as well as short transporting form, suggesting a possible role for leptin in foetal growth and development (124). However, no correlation between maternal leptin levels and birth weight was found $(116,119,120)$, in contrast to cord serum leptin concentrations and leptin levels in infants at birth, which are correlated with birth weight $(57,58,116,120)$.

The drop in leptin levels seen after delivery could play a role in the reduced fertility during the period of lactation.

\section{Polycystic ovary syndrome}

Women with the polycystic ovary syndrome (PCOS) are hyperandrogenic, with increased plasma androstenedione and testosterone levels, are often characterized by visceral obesity, hyperinsulinaemia and insulin resistance, and are frequently subfertile or even infertile. Leptin status in these women is not clear. Several studies found leptin levels in women with PCOS to be higher than expected for their BMI (125-128), but other studies found leptin levels comparable with age- and weight-matched control women (129-132). A possible explanation for these different findings could be that the phenotype of PCOS can vary considerably, and that not all women with PCOS are to the same degree (abdominally) obese. The variability in leptin levels can possibly be explained in part by differences in body composition. But even with similar leptin levels, the activity could differ in women with PCOS, for example by a different proportion of bound leptin circulating in the blood, differences in leptin pulsatility, or a reduced sensitivity of the hypothalamic-pituitary-ovary axis in women with PCOS (133).

\section{Menopause}

It has been proposed that a decrease in leptin levels found at menopause was due to the fall in oestrogen levels $(53,68)$. However, most other studies found no differences in leptin levels between pre- and postmenopausal women, when matched for BMI (52, $54,114,134,135)$. Hormone replacement therapy (with oestrogens and progesterone) does not seem to affect leptin levels in post-menopausal women either $(52,114,134,136,137)$. From these data it seems unlikely that the presence of oestrogens is responsible for the higher leptin levels seen in women. Since postmenopausal women still have higher leptin levels compared with men, the suppressive effect of circulating androgens may also play a role.

These experimental in vitro and in vivo data altogether indicate that an interaction between leptin and sex steroids exists, but the physiological importance and working mechanisms are not yet clear. Yet, although the exact mechanisms are still unknown at this moment, it is clear that leptin is important in the regulation of reproductive function, and this in men as well as in mice.

The gender difference in leptin levels seems to be explained by differential effects of sex hormones, in particular an inhibition by testosterone, in addition to the differences in body composition, with women having more subcutaneous fat, secreting more leptin.

\section{Leptin and insulin metabolism}

A possible interaction between leptin and insulin was first suggested by the strong correlations between fasting serum leptin and insulin levels observed in human studies, independent of body fatness $(54,55$, 138-140). The question arose whether there is a causal relationship or not, and in which direction. In other words, is leptin secretion regulated by insulin, or can leptin have an influence on insulin secretion and action? 


\section{Effect of insulin on leptin secretion}

More and more convincing evidence emerges that insulin can regulate leptin expression. This is most evident from studies with isolated adipocytes, which all showed that in vitro insulin clearly stimulates the mRNA expression and secretion of leptin in cultured rat and human adipocytes (141-145). In isolated adipocytes, glucose metabolism seems to be an important determinant of the regulation of leptin expression and secretion.

Also, rodent studies showed that insulin induced an increase in $o b$ mRNA in adipose tissue $(141,146,147)$ and increased plasma leptin levels (148-150). Rats made insulin deficient by streptozotocin (STZ) treatment show significantly reduced leptin levels; when these STZ-treated animals receive an insulin injection, leptin secretion increases rapidly again $(146,149,150)$. Similarly, in diabetic rats the reduced plasma leptin levels found under conditions of insulin deficiency are also raised by insulin treatment (150).

In human experiments, hyperinsulinaemia induced by clamp techniques leads to a rise in leptin concentrations, but only in the longer term $(143,151-153)$, not acutely $(51,138,143,154,155)$. Serum leptin levels are raised by insulin treatment, in type 2 as well as type 1 diabetic patients $(140,156)$. One report on a patient with insulinoma reported markedly elevated leptin levels during chronically high insulinaemia, which both dropped after surgical removal (157), also indicating that chronic hyperinsulinaemia increases leptin expression.

\section{Effect of leptin on insulin secretion}

More and more data provide evidence for the assumption that leptin can modulate insulin secretion and action, exerting insulin- and glucose-lowering effects.

In the $o b / o b$ mice, characterized by hyperglycaemia, hyperinsulinaemia and insulin resistance, leptin treatment can correct all these metabolic abnormalities, even before weight loss occurs $(9,15,158)$. In normal fed mice a decrease in plasma insulin and associated rise in glucose were observed after leptin administration (159, 160), while infusion of leptin to fasted rats reduced both glucose and insulin (161). This seems to be due to effects on insulin action as well as on insulin release. No direct effect of leptin i.v. or i.c.v. on insulin secretion is found in intact animals, but an acute inhibition of insulin release by leptin was seen in vagotomized rats, which could in turn be blocked by sympathectomy (162). This suggests that a reduction in insulin secretion could be induced by leptin in intact animals, mediated through sympathetic activation under very specific conditions (163).

Functional leptin receptors were shown to be present on insulin-secreting pancreatic $\beta$-cells (164). The insulin-lowering effect of leptin administration could thus be mediated through these receptors. A direct inhibition of leptin on basal and glucose-stimulated insulin secretion was shown in pancreatic islets, at least with high concentrations or prolonged exposure (159, 165-172). Though some other studies found conflicting results, the effect of leptin on insulin release seems to be specific, since no response is seen in tissue from leptin receptor-deficient $d b / d b$ mice or $f a / f a$ rats (159). The proposed mechanism seems to affect the phospholipase $\mathrm{C}$ (PLC)/protein kinase C (PKC)-mediated pathway regulating insulin secretion. Modulation by leptin of several steps in this pathway were described: lowering of intracellular $\mathrm{Ca}^{2+}$ concentration and activation of ATP-sensitive $\mathrm{K}^{+}$channels $(166,169,173)$; a specific inhibition of PLC-mediated insulin secretion, which is enhanced in $o b / o b$ mice $(167,174)$; and reduction of $\mathrm{PKC}$, a $\mathrm{Ca}^{2+}$-dependent mediator in the second phase of the PLC signal pathway $(167,170)$. The insulinsuppressive effect of leptin could also partly be mediated by activation of phosphodiesterase 3B (171, 175), leading to suppression of cAMP levels and inhibition of GLP-1-stimulated insulin secretion. Recently, a direct effect of leptin on insulin gene transcription in pancreatic $\beta$-cells was shown, with a reduction of preproinsulin mRNA by $50 \%(168,176)$. Leptin probably acts at different intracellular levels, from transcription to membrane permeability, to inhibit insulin synthesis as well as secretion.

\section{Effects of leptin on insulin action}

The fact that the leptin receptor is expressed in liver, skeletal muscle and adipocytes suggests that leptin might influence the function of these three classical insulin target tissues, and could possibly affect the response to insulin in these tissues.

In vivo studies show that leptin has an effect on glucose utilization. Central or i.v. infusion of leptin to rats enhances hepatic and peripheral insulin sensitivity and increases whole-body glucose utilization (161, 177-180). When $o b / o b$ mice are treated with leptin, a normalization of blood glucose is seen (9). The question is whether this is the result of the weight loss induced by leptin, or whether leptin has a direct action lowering blood glucose, e.g. through enhancing (peripheral) insulin sensitivity. When $o b / o b$ mice treated with leptin were compared with pair-fed mice, both showed, besides a decrease in body weight, lowered glucose and insulin levels, but the decrease in insulin in pair-fed, non-leptin-treated mice was only $60 \%$ of that observed in leptin-treated mice (181). A recent study compared the effect of decreased visceral adiposity induced by leptin, a $\beta 3$-adrenoceptor agonist, or food restriction, on insulin action in rats (180). They found that hepatic insulin action increased similarly in the three treatment groups, but peripheral insulin action was only significantly increased by leptin treatment (180). So, leptin seems to exert a hypoglycaemic action which is partly independent of its weight- or fat-reducing effects. In 
addition, this action of leptin on glucose metabolism seems to be partly independent of its effect on insulin, as was shown in a study on STZ-induced diabetic rats, where leptin treatment could normalize blood glucose and improve insulin sensitivity without the use of insulin (179).

Leptin receptors are present on human hepatocytes, and leptin was shown to modulate several insulininduced activities in these cells (182). Leptin antagonizes insulin signalling, by decreasing insulin-induced tyrosine phosphorylation of IRS-1 (182); it increases PEP-carboxykinase $(183,184)$ and decreases glucokinase expression (183), leading to increased gluconeogenesis and decreased glycogenolysis $(183,184)$. The hepatic effects of high leptin levels may thus contribute to hepatic insulin resistance.

Studies on other peripheral tissues show no consistent results. Some studies indicate that leptin is able to modulate insulin action (on glucose uptake and/or lipid synthesis) in adipocytes (160, 177, 185-187) and muscle cells $(177,188-191)$, but other studies found no effect on peripheral glucose uptake (183, 184, 192-196).

\section{Leptin and diabetes}

The question was raised some years ago as to whether leptin was important in the development of type 2 diabetes $(197,198)$. As discussed previously, leptin can impair insulin production, and some data indicate that leptin could also play a role in the development of peripheral insulin resistance. Thus, a hypothesis for the interference of leptin in the development of insulin resistance and type 2 diabetes in obese subjects could be that high leptin levels as observed in obesity lead to hyperglycaemia through suppression of the glucoseinduced insulin secretion by the pancreas. Peripheral insulin resistance, possibly also induced by hyperleptinaemia, may then add to a further glucose intolerance, overruling this leptin-induced suppression of insulin secretion and eventually induce hyperinsulinaemia. Another hypothesis is that the high serum leptin levels in obesity result in desensitization of the receptor and thus defective leptin receptor signalling in $\beta$-cells, which leads to chronic hyperinsulinaemia and may thus contribute to the pathogenesis of diabetes (172).

On the other hand, leptin could have a protective antidiabetic effect, by enhancing peripheral insulin sensitivity and by decreasing triglyceride accumulation in several tissues $(199,200)$.

At this moment, there is no evidence for involvement of mutations in the leptin or leptin receptor gene in the development of type 2 diabetes or impaired glucose tolerance. No mutations were found in screenings of the human $o b$ gene and its promotor in type 2 diabetic subjects $(18,20)$, and leptin levels are comparable in type 2 diabetic patients and nondiabetics when BMI or fat mass is taken into account $(139,201-203)$.
Associations of leptin with body composition, gender differences as well as correlations with insulin are also similar in diabetic patients as in non-diabetics (140, 156, 203).

In short, leptin has been shown to inhibit insulin secretion at the level of the pancreas, while concomitantly enhancing insulin action and glucose utilization. On the other hand, leptin production by the adipocyte seems to be critically dependent on insulin. In humans, insulin and leptin levels are associated, but whether insulin can acutely regulate leptin levels in humans remains controversial. A change in leptin levels is observed in response to insulin, but only with a certain delay. Presumably this stimulatory effect of insulin on leptin secretion is, at least partly, due to the trophic effect of insulin on adipocytes.

\section{Leptin and the corticotrophic (HPA) axis}

Obesity is often associated with an increased cortisol turnover rate (increased production and accelerated degradation) or with hyper-responsiveness of the hypothalamic-pituitary-adrenal (HPA) axis. Glucocorticoids have been shown to modulate food intake and body weight. They have a central effect on the central nervous system, stimulating anabolic effector pathways like NPY, and inhibiting catabolic pathways like $\mathrm{CRH}$ and $\alpha$-melanocyte-stimulating hormone $(\alpha-\mathrm{MSH})$. The question was raised whether this effect could partly be mediated through leptin.

Leptin and cortisol levels are inversely related in humans $(103,157,204)$. It is suggested that leptin can regulate the HPA axis both centrally, at the level of hypophysiotrophic $\mathrm{CRH}$, and peripherally, at the level of the adrenal gland.

Centrally, leptin suppresses the HPA axis. In fasted rodents with reduced leptin levels, increased plasma corticosterone and adrenocorticotrophic hormone (ACTH) are seen, which can be blunted by leptin administration $(98,101)$. Leptin deficient $o b / o b$ mice are hypercortisolaemic, also reversible by leptin treatment $(15,98)$. Increased corticosterone levels are also seen in $d b / d b$ mice (98) and $f a / f a$ rats $(205)$, rodent models of obesity both characterized by leptin resistance. The mechanism of this suppression of the HPA axis by leptin is presumably hypothalamic, as leptin has been shown in vitro to blunt the release of $\mathrm{CRH}$ induced by hypoglycaemia in isolated hypothalamic neurons, but not altering the secretion of ACTH from isolated pituitary cells (206). In addition, the presence of leptin in pituitary ACTH cells was also shown recently (86). Moreover, leptin could also suppress the HPA axis by inhibition of NPY, which normally activates the HPA axis.

Leptin receptors are present in adrenal tissue, cortex as well as medulla $(207,208)$. In vitro, it was clearly shown that leptin can directly modulate adrenal corticosteroid secretion: incubation of adrenocortical 
cells with leptin inhibits basal cortisol secretion and ACTH-induced cortisol, aldosterone, and dehydroepiandrosterone release $(207,209-211)$.

In human leptin deficiency, normal plasma cortisol levels were reported, with slightly elevated ACTH, and reduction of plasma cortisol and free urinary cortisol by administration of $1 \mathrm{mg}$ of dexamethasone (21-23). In leptin receptor deficiency, normal ACTH and cortisol levels were reported, a normal dexamethasone test and slightly elevated free urinary cortisol levels, normal for the degree of obesity of these subjects (28).

Glucocorticoids are potent regulators of leptin expression. Cortisol has been shown to stimulate leptin production in vitro and in vivo.

In vitro studies on isolated adipocytes showed a clear stimulatory effect of glucocorticoids on leptin synthesis and secretion $(144,145,212,213)$.

Peripheral infusion of glucocorticoids to rats induced $o b$ gene expression in adipose tissue and hyperleptinaemia, followed by a decrease in food consumption and a subsequent lower body weight gain than controls $(214,215)$. Thus, the catabolic actions of high doses of corticosteroids, resulting in an inhibition of food intake and a decrease of body weight in rodents might be mediated by an increase of adipocyte leptin mRNA expression. Yet, when glucocorticoids were infused centrally, marked increases in food intake and body weight were seen, with increased levels of NPY and decreased CRH, besides hyperleptinaemia, hyperinsulinaemia and hypertriglyceridaemia (215). This observation provides evidence for the thesis that the known stimulatory effect of corticosteroids on food intake and body weight is a central action, which could partly be counter-regulated through the peripheral induction of leptin. However, the increase in leptin secretion could also be due to the elevated insulin levels induced by corticosteroid administration $(142,215)$.

In humans, administration of glucocorticoids increases leptin secretion (216-222), though acute stimulation of the corticotrophic axis did not always significantly alter leptin levels $(45,204,222)$. It was suggested that chronic hypersecretion of cortisol could be involved in inducing not only hyperleptinaemia but also leptin resistance in some groups of obese humans (223).

Patients with Cushing's syndrome, a state of glucocorticoid excess marked by central fat accumulation, have markedly elevated serum leptin levels independent of adiposity which could be a result of the increased glucocorticoid levels, but could also partly be attributed to the associated hyperinsulinaemia (224-226). Tumour resection of adrenal or pituitary adenoma causes a marked reduction in leptin levels concomitant with the decline in cortisol levels $(225,226)$.

On the other hand, glucocorticoids seem to have an inhibitory effect on leptin action. This was illustrated in adrenalectomized rats, where leptin administration had potent effects on food intake and body weight, which were inhibited by glucocorticoid supplementation (227).
These overall findings, the direct inhibitory effect of leptin on cortisol secretion by the adrenal gland on one hand, and the potent stimulatory effects of glucocorticoids on leptin expression on the other hand, suggest the existence of a negative feedback loop between leptin and glucocorticoids. In addition, it has been suggested that glucocorticoids may also have an inhibitory effect on the central action of leptin (227).

\section{Leptin and the thyroid axis}

Thyroid function is linked to energy expenditure, and its hormone increases metabolic rate, thus being a major regulator of energy homeostasis. Alterations in thyroid status often result in changes in body weight and energy metabolism, with hyperthyroidism increasing thermogenesis and hypothyroidism decreasing basal metabolic rate and body temperature. Since leptin and thyroid hormones have similar effects on thermogenesis and energy metabolism, the possibility has been raised that they could both exert their effects through the same pathways, i.e. regulation of sympathetic nervous system activity, mainly adrenergic upregulation.

Regulation of thyroid hormone (thyroxine $\left(\mathrm{T}_{4}\right)$ and tri-iodothyronine $\left(\mathrm{T}_{3}\right)$ ) secretion originates in the hypothalamic paraventricular nucleus (PVN), where thyrotrophin-releasing hormone (TRH) is produced, which regulates thyroid-stimulating hormone (TSH) secretion by the anterior pituitary gland. Leptin seems to influence the feedback regulation of the hypothalamic TRHsecreting neurons by thyroid hormone. This central effect may be mediated through NPY and/or CRF, as neurons expressing these peptides were shown to interact with TRH-synthesizing neurons in the hypothalamus $(228,229)$. At the level of the pituitary gland, leptin was recently shown to be expressed by TSH cells too (86).

Prolonged fasting is associated with a fall in leptin levels and in thyroid hormones. Leptin administration to fasted mice decreased the fall in $\mathrm{T}_{4} / \mathrm{TSH}$ induced by fasting (101), restored the reduced plasma levels of total and free $\mathrm{T}_{3}$ and $\mathrm{T}_{4}$ to normal levels, as well as the suppressed proTRH mRNA in PVN neurons (230). The same group also showed that peak levels of leptin precede peak $\mathrm{T}_{4}$ levels in food-restricted mice (101). They suggested that leptin has a selective, central action modulating the hypothalamic-pituitary-thyroid axis by regulating proTRH gene expression in the PVN without peripheral effects in thyroid-binding proteins. Thus, adaptation to starvation can take place because the fall in circulating leptin levels during fasting resets the set point for feedback inhibition by thyroid hormones on the biosynthesis of hypophysiotrophic proTRH, thereby restoring reduced thyroid hormone levels towards normal and reversing the central hypothyroid state.

In human mutations of the leptin gene and of the leptin receptor gene, some abnormalities of the thyroid axis have been reported, without it being clear if these 
are really caused by the defective leptin function. In human leptin deficiency, elevated TSH levels were reported in children with the genetic defect $(21,23)$, whereas these were normal in the adult patients $(22,23)$. In the human leptin receptor mutation, a hypothalamic hypothyroidism was seen, with reduced secretion of thyrotrophin, low levels of free thyroxin, normal basal TSH levels but a sustained TSH response to a TRH stimulation test (28).

The question is raised as to whether thyroid hormones modulate leptin expression or secretion. Theoretically, one would expect an inhibitory effect of thyroid hormones on leptin secretion, since thyroid hormones have a permissive role on the effects of catecholamines on betaadrenergic receptors, and since stimulation of these receptors suppresses leptin expression (231). This seems consistent with the inverse relation which is seen between leptin and thyroid hormone levels.

This theory is confirmed by rodent data, where thyroid hormones seem to exert a negative influence on serum leptin levels. Leptin was elevated in thyroidectomized rats compared with controls, and infusion of $\mathrm{T}_{3}$ or $\mathrm{T}_{4}$ to these rats decreased leptin levels (232). Administration of $\mathrm{T}_{3}$ to hypothyroid rats also decreased leptin mRNA expression in adipose tissue and circulating leptin levels (231).

In vitro, however, an upregulation of leptin by thyroid hormone in differentiated adipocytes was shown. $\mathrm{T}_{3}$, but not $\mathrm{T}_{4}$, stimulated $o b$ mRNA expression and leptin secretion by adipocytes in vitro (233).

Human studies show no conclusive evidence on this relation between thyroid hormone and leptin levels. In normal healthy men, administration of $\mathrm{T}_{3}$ for 1 week had no effect on circulating leptin levels (234). Possible effects of low versus high thyroid hormone levels on leptin levels were studied in hypothyroid and hyperthyroid patients, with conflicting results. In hyperthyroid patients, one study found increased leptin levels (235), one found decreased leptin levels (236), while other studies found no significant differences with controls (237-240). In hypothyroid patients, some studies found decreased leptin levels $(237,238)$, while others found levels comparable with controls (235, 241, $242)$, or even higher $(236,239)$, which seems consistent with the relatively higher body fat in these patients. Treatment of hypothyroid patients with $\mathrm{T}_{4}$ resulted in two studies in normalization of the decreased (237) and increased (236) leptin levels in some studies, but in other studies no significant change in leptin levels was seen after normalization of thyroid function $(235,243)$. So, altogether, thyroid dysfunction seems not to have a significant effect on leptin levels in man.

\section{Leptin and the $\mathrm{GH}$ axis}

Growth hormone is not only involved in growth and development, but also has an important impact on body composition and fat distribution, through its influence on energy metabolism, its lipolytic and nitrogen sparing effects. Furthermore, obesity is associated with disturbances in the GH-insulin-like growth factor-I (IGF-I) axis. Serum levels of GH and IGF-binding proteins are often decreased in obese subjects (244), resulting in high free IGF-I levels. Starvation on the other hand leads to increased GH secretion in humans (245). Administration of $\mathrm{GH}$ stimulates energy expenditure (246) and decreases the amount of body fat.

Furthermore, leptin is structurally related to $\mathrm{GH}$, since both belong to the family of helical cytokines (247), and the possibility of binding of leptin to GH binding proteins may therefore not be excluded.

The effect of leptin on GH secretion has not as yet been very extensively investigated. Leptin, as it is increased in obesity, may act as a signal reducing GH secretion. This action could take place through leptin receptors which are present in those hypothalamic nuclei known to be involved in GH regulation (248). Leptin inhibits somatostatin gene expression and secretion in hypothalamic neurons (249). The leptin receptor is also expressed at the level of the pituitary gland, where leptin has been shown to specifically stimulate basal GH release $(250,251)$. Moreover, the long form of the leptin receptor seems to be upregulated by growth hormone-releasing hormone (GHRH), as was shown in the pituitary gland of hGHRH transgenic mice (252). Leptin is also expressed by pituitary GH adenomas, and co-localization of leptin with GH in anterior pituitary cells has been shown (86).

Rodent experiments on the contrary point to a stimulatory action of leptin on GH secretion. Central infusion of leptin to rats stimulates basal GH secretion $(248,251,253,254)$. Administration of leptin antiserum to normal fed rats led to a decrease in spontaneous GH secretion (255). Administration of leptin to fasted rats was followed by a reversal of the fasting-induced suppression of GH secretion, suggesting a role for leptin in the regulation of $\mathrm{GH}$ secretion (253, 256).

No human studies are available, and since regulation of the GH axis in humans is different from rodents, no conclusions can be drawn from these experiments. Only indirect data are available indicating that leptin is involved in regulation of GH secretion. Some (257-259), though not all (260), studies find an inverse correlation between leptin and GH in humans. A study in prepubertal children identified leptin as a negative determinant of the $\mathrm{GH}$ response to stimulation tests (258). In patients with human leptin or leptin receptor deficiency, impaired GH secretion in response to stimulation tests was reported $(23,28)$.

Whether leptin secretion is also influenced by GH is not yet clear. Most studies point towards an inhibitory effect of the GH axis on leptin secretion. It is, however, not clear if this is a direct effect or rather indirect through stimulation of lipolysis in adipocytes. 
The GH receptors, as expressed on adipocytes, could mediate a direct effect of $\mathrm{GH}$ on leptin synthesis by the adipocyte. In vitro chronic incubation of isolated adipocytes with either GH or IGF-I however had no effect on leptin expression and secretion (145).

A recent study showed a suppressive effect on leptin and insulin of recombinant human (rh) IGF-I infusion in normal rats, but no effect of rhGH infusion (261). This suppressive effect could be due to the reduced circulating insulin, leading to enhanced fat mobilization and oxidation. Administration of IGF-I to renal impaired patients decreased leptin levels (262), suggesting that in humans too, IGF-I may have an inhibitory effect on leptin secretion.

Acute $\mathrm{GH}$ administration to healthy humans has no effect on leptin levels $(263,264)$. In men with abdominal obesity (and low IGF-I levels), long term GH treatment decreased serum leptin levels after 6 weeks, but after 9 months no changes in serum leptin levels and leptin mRNA expression were found despite a loss of fat mass (265). Infusion with somatostatin, insulin and $\mathrm{GH}$ for $2 \mathrm{~h}$ significantly reduced plasma leptin in normal weight subjects (266).

In hypopituitary patients with GH deficiency, who are characterized by increased fat mass and especially abdominal (visceral) fat accumulation (246), leptin levels were shown to be higher than in controls, matched for age and BMI (257, 267-270). The normal circadian rhythm of leptin is preserved in these patients $(270,271)$. Treatment with GH replacement therapy leads to a change in body composition, with an increase in lean body mass and a decrease in fat mass (272). Since leptin levels are strongly associated with fat mass, it can be expected that changes in plasma leptin levels will occur during treatment with GH. Most reports on GH treatment in these patients show a decrease in leptin levels, concomitant with the decreases in percentage body fat $(264,269,273,274)$, but not independent of changes in body composition (264).

In conclusion, leptin could possibly be a metabolic signal inhibiting GH secretion, while GH/IGF-I could be involved in the regulation of leptin secretion, but it is not clear whether this is a direct effect or only an indirect effect through changes in body composition and insulin.

\section{In summary: an overview of leptin physiology}

Leptin is produced and secreted mainly by adipose tissue, but also by placenta and stomach, bone marrow and muscle (possibly by adipose cells in these last two tissues), and even pituitary cells. Leptin expression is regulated in humans by fasting and feeding, by insulin, glucocorticoids and possibly also other hormones, and by $\beta$-adrenergic action on adipocytes.

The hypothalamus is the principal site of action for leptin. Receptors were first identified in the brain, at different sites (choroid plexus, arcuate nucleus, the ventromedial, dorsomedial and paraventricular nuclei) but also in a variety of peripheral tissues such as lung and kidney (where clearance takes place), and at lower levels in liver, pancreatic $\beta$-cells, adrenal tissue, adipose tissue, skeletal muscle, gonads, T-lymphocytes and epithelial cells, providing evidence for its role not only in energy balance, but also in carbohydrate metabolism, reproduction and several other functions.

These different actions play on a different time scale: the effect of leptin on food intake is an acute effect; metabolic effects on glucose metabolism take place within hours; in days leptin can change gene expression in the CNS; the effects on weight and body composition need several days or weeks; support of puberty is an even longer-term effect.

In conclusion, leptin can no longer be called a mere adipocyte-secreted hormone with a weight regulatory function, but is more and more emerging as a hormone with an important (neuro-) endocrine and metabolic role, acting through the hypothalamus as well as peripherally on pathways varying from glucose metabolism regulation to sexual maturation and reproduction.

\section{References}

1 Zhang Y, Proenca R, Maffei M, Barone M, Leopold L \& Friedman JM. Positional cloning of the mouse obese gene and its human homologue. Nature 1994372 425-431.

2 Considine RV, Sinha MK, Heiman ML, Kriauciunas, Stephens TW, Nyce MR et al. Serum immunoreactive-leptin concentrations in normal-weight and obese humans. New England Journal of Medicine 1996334 292-295.

3 Lönnqvist F, Arner P, Nordfors L \& Schalling M. Overexpression of the obese $(o b)$ gene in adipose tissue of human obese subjects. Nature Medicine 19951 950-953.

4 Hamilton BS, Paglia D, Kwan AY \& Deitel M. Increased obese mRNA expression in omental fat cells from massively obese humans. Nature Medicine 1995 1 953-956.

5 Maffei M, Halaas J, Ravussin E, Pratley RE, Lee GH, Zhang Yet al. Leptin levels in human and rodent: measurement of plasma leptin and $o b$ RNA in obese and weight-reduced subjects. Nature Medicine 19951 1155-1161.

6 Kennedy GC. The role of depot fat in the hypothalamic control of food intake in the rat. Proceedings of the Royal Society 1953140 578-592.

7 Coleman DL. Effects of parabiosis of obese with diabetes and normal mice. Diabetologia 19739 294-298.

8 Masuzaki H, Ogawa Y, Isse N, Satoh N, Okazaki T, Shigemoto M et al. Human Obese gene expression - adipocyte-specific expression and regional differences in the adipose tissue. Diabetes $199544855-858$.

9 Pelleymounter M, Cullen M, Baker M, Hecht R, Winters D, Boone $\mathrm{T}$ et al. Effects of the obese gene product on body weight regulation in ob/ob mice. Science 1995269 540-543.

10 Halaas J, Gajiwala K, Maffei M, Cohen SL, Chait BT, Rabinowitz D et al. Weight-reducing effects of the plasma protein encoded by the obese gene. Science 1995269 543-546.

11 Campfield LA, Smith FJ, Guisez Y, Devos R \& Burn P. Recombinant mouse OB protein: evidence for a peripheral signal linking adiposity and central neural networks. Science $1995269546-549$.

12 Tartaglia LA, Dembski M, Weng X, Deng N, Culpepper J, Devos R et al. Identification and expression cloning of a leptin receptor, OB-R. Cell 199583 1263-1271. 
13 Schwartz MW, Seeley RJ, Campfield LA, Burn P \& Baskin DG. Identification of leptin action in rat hypothalamus. Journal of Clinical Investigation 199698 1101-1106.

14 Kalra SP, Dube MG, Pu S, Xu B, Horvath TL \& Kalra PS. Interacting appetite-regulating pathways in the hypothalamic regulation of body weight. Endocrine Reviews 199920 68-100.

15 Stephens TW, Basinski M, Bristow PK, Bue-Vallesky JM, Burgett SG, Craft L et al. The role of neuropeptide Y in the antiobesity action of the obese gene product. Nature 1995377 530-532.

16 Considine RV, Considine EL, Williams CJ, Nyce MR, Magosin SA, Bauer TL et al. Evidence against either a premature stop codon or the absence of obese gene mRNA in human obesity. Journal of Clinical Investigation 199595 2986-2988.

17 Considine RV, Considine EL, Williams CJ, Nyce MR, Zhang P, Opentanova I et al. Mutation screening and identification of a sequence variation in the human $O B$ gene coding region. Biochemical and Biophysical Research Communications 1996220 735-739.

18 Maffei M, Stoffel M, Barone M, Moon B, Dammerman M, Ravussin $\mathrm{E}$ et al. Absence of mutations in the human $O B$ gene in obese/diabetic subjects. Diabetes 199645 679-682.

19 Niki T, Mori H, Tamori Y, Kishimoto-Hashiramoto M, Ueno H, Araki S et al. Human obese gene: molecular screening in Japanese and Asian Indian NIDDM patients associated with obesity. Diabetes 199645 675-678.

20 Shigemoto M, Nishi S, Ogawa Y, Isse N, Matsuoka N, Tanaka T et al. Molecular screening of both the promoter and the protein coding regions in the human $o b$ gene in Japanese obese subjects with non-insulin-dependent diabetes mellitus. European Journal of Endocrinology 1997137 511-513.

21 Montague CT, Farooqi IS, Whitehead JP, Soos MA, Rau H, Wareham NJ et al. Congenital leptin deficiency is associated with severe early-onset obesity in humans. Nature $1997387903-$ 908 .

22 Strobel A. Issad T, Camoin L, Ozata M \& Strosberg AD. A leptin missense mutation associated with hypogonadism and morbid obesity. Nature Genetics 199818 213-215.

23 Ozata M, Ozdemir IC \& Licinio J. Human leptin deficiency caused by a missense mutation: multiple endocrine defects, decreased sympathetic tone, and immune system dysfunction indicate new targets for leptin action, greater central than peripheral resistance to the effects of leptin, and spontaneous correction of leptin-mediated defects. Journal of Clinical Endocrinology and Metabolism 199984 3686-3695.

24 Farooqi IS, Jebb SA, Langmack G, Lawrence E, Cheetham $\mathrm{CH}$, Prentice AM et al. Effects of recombinant leptin therapy in a child with congenital leptin deficiency. New England Journal of Medicine $1999341879-884$.

25 Caro JF, Sinha MK, Kolaczynski JW, Zhang PL \& Considine RV. Leptin: the tale of an obesity gene. Diabetes $1996451455-$ 1462.

26 Considine RV, Considine EL, Williams CJ, Hyde TM \& Caro JF. The hypothalamic leptin receptor in humans: identification of incidental sequence polymorphisms and absence of the $d b / d b$ mouse and $f a / f a$ rat mutations. Diabetes $199619992-994$.

27 Rolland V, Clément K, Dugail I, Guy-Grand B, Basdevant A, Froguel $\mathrm{P}$ et al. Leptin receptor gene in a large cohort of massively obese subjects: no indication of the $f a / f a$ rat mutation. Detection of an intronic variant with no association with obesity. Obesity Research $19986122-127$.

28 Clément K, Vaisse C, Lahlou N, Cabrol S, Pelloux V, Cassuto D et al. A mutation in the human leptin receptor gene causes obesity and pituitary dysfunction. Nature 1998392 398-401.

29 Thompson DB, Ravussin E, Bennett PH \& Bogardus C. Structure and sequence variation at the human leptin receptor gene in lean and obese Pima Indians. Human and Molecular Genetics 19976 675-679.

30 Chung WK, Power-Kehoe L, Chua M, Chu F, Aronne L, Huma Z et al. Exonic and intronic sequence variation in the human leptin receptor gene (LEPR). Diabetes 199746 1509-1511.
31 Echwald SM, Sorensen TD, Sorensen TI, Tybjaerg-Hansen A, Andersen T, Chung WK et al. Amino acid variants in the human leptin receptor: lack of association to juvenile onset obesity. Biochemical and Biophysical Research Communications 1997233 248-252.

32 Matsuoka N, Ogawa Y, Hosoda K, Matsuda J, Masuzaki H, Miyawaki T et al. Human leptin receptor gene in obese Japanese subjects: evidence against either obesity-causing mutations or association of sequence variants with obesity. Diabetologia 1997 $401204-1210$.

33 Francke S, Clément K, Dina C, Inoue H, Behn P, Vatin V et al. Genetic studies of the leptin receptor gene in morbidly obese French Caucasian families. Human Genetics 1997100 491496.

34 Silver K, Walston J, Chung WK, Yao F, Parikh VV, Andersen R et al. The Gln223Arg and Lys656Asn polymorphisms in the human leptin receptor do not associate with traits related to obesity. Diabetes 199746 1898-1900.

35 Gotoda T, Manning BS, Goldstone AP, Imrie H, Evans AL, Strosberg AD et al. Leptin receptor gene variation and obesity: lack of association in a white British male population. Human and Molecular Genetics 19976 869-876.

36 Chagnon YC, Chung WK, Pérusse L, Chagnon M, Leibel RL \& Bouchard C. Linkages and associations between the leptin receptor (LEPR) gene and human body composition in the Québec Family Study. International Journal of Obesity 199923 278-286.

37 Wauters M, Mertens I, Gaal LV \& Bouchard C. Associations between leptin receptor gene polymorphisms and obesity-related phenotypes in obese women. International Journal of Obesity 199923 S30.

38 Heo M, Leibel RL, Boyer BB, Chung WK, Koulu M, Karvonen M et al. A preliminary meta-analysis of the association of LEPR polymorphisms with anthropometric variables. Obesity Research $1999737 \mathrm{~S}$.

39 Sinha MK, Opentanova I, Ohannesian JP, Kolaczynski JW, Heiman ML, Hale J et al. Evidence of free and bound leptin in human circulation - studies in lean and obese subjects and during short-term fasting. Journal of Clinical Investigation 1996 98 1277-1282.

40 Banks WA, Kastin AJ, Huang W, Jaspan JB \& Maness LM. Leptin enters the brain by a saturable system independent of insulin. Peptides 199617 305-311.

41 Schwartz M, Peskind E, Raskind M, Boyko EJ \& Porte D. Cerebrospinal fluid leptin levels: relationship to plasma levels and to adiposity in humans. Nature Medicine 19962 589-593.

42 Caro JF, Kolaczynski JW, Nyce MR, Ohannesian JP, Opentanova I, Goldman WH et al. Decreased cerebrospinal-fluid/serum leptin ratio in obesity: a possible mechanism for leptin resistance. Lancet 1996348 159-161.

43 Van Heek M, Compton DS, France CF, Tedesco RP, Fauzi AB, Graziano MP et al. Diet-induced obese mice develop peripheral, but not central, resistance to leptin. Journal of Clinical Investigation 199799 385-390.

44 Elmquist JK, Elias CF \& Saper CB. From lesions to leptin: hypothalamic control of food intake and body weight. Neuron 199922 221-232.

45 Vettor R, Vicennati V, Gambineri A, Pagano C, Calzoni F \& Pasquali R. Leptin and the hypothalamic-pituitary-adrenal axis activity in women with different obesity phenotypes. International Journal of Obesity 199721 708-711.

46 Ramachandran A, Snehalatha C, Vijay V, Satyavani K, Latha E \& Haffner S. Plasma leptin in non-diabetic Asian Indians: association with abdominal adiposity. Diabetic Medicine 1997 14 937-941.

47 Wauters M, Mertens I, Considine R, Leeuw ID \& Van Gaal L. Are leptin levels dependent on body fat distribution in obese men and women? Eating and Weight Disorders 19983 124-130.

48 Hube F, Lietz U, Igel M, Jensen PB, Tornqvist H, Joost H-G et al. Difference in leptin mRNA levels between omental and 
subcutaneous abdominal adipose tissue from obese humans. Hormone and Metabolic Research 199628 690-693.

49 Montague CT, Prins JB, Sanders L, Digby JE \& O’Rahilly S. Depotand sex-specific differences in human leptin mRNA expression. Diabetes 199746 342-347.

50 Lefebvre A-M, Laville M, Vega N, Riou J-P, Van Gaal L, Auwerx J et al. Depot-specific differences in adipose tissue gene expression in lean and obese subjects. Diabetes 199847 98-103.

51 Dagogo-Jack S, Fanelli C, Paramore D, Brothers J \& Landt M. Plasma leptin and insulin relationships in obese and nonobese humans. Diabetes 199645 695-698.

52 Havel PJ, Kasim-Karakas S, Dubuc GR, Mueller W \& Phinney SD. Gender differences in plasma leptin concentrations. Nature Medicine 19962 949-950.

53 Rosenbaum M, Nicholson M, Hirsch J, Heymsfield SB, Gallagher D, Chu F et al. Effects of gender, body composition and menopause on plasma concentrations of leptin. Journal of Clinical Endocrinology and Metabolism 199681 3424-3427.

54 Saad MF, Damani S, Gingerich RL, Riad-Gabriel MG, Khan A, Boyadjian $\mathrm{R}$ et al. Sexual dimorphism in plasma leptin concentration. Journal of Clinical Endocrinology and Metabolism 199782 579-584.

55 Couillard C, Mauriege P, Prud'homme D, Nadeau A, Tremblay A, Bouchard $\mathrm{C}$ et al. Plasma leptin concentrations: gender differences and associations with metabolic risk factors for cardiovascular disease. Diabetologia 199740 1178-1184.

56 Tome MA, Lage M, Camina JP, Garcia-Mayor RV, Dieguez C \& Casanueva FF. Sex-based differences in serum leptin concentrations from umbilical cord blood at delivery. European Journal of Endocrinology 1997137 655-658.

57 Hassink SG, de Lancey E, Sheslow DV, Smith-Kirwin SM, O'Connor DM, Considine RV et al. Placental leptin: an important new growth factor in intrauterine and neonatal development? Pediatrics 1997100124 (e1)

58 Matsuda J, Yokota I, Iida M, Murakami T, Naito E, Ito M et al. Serum leptin concentration in cord blood: relationship to birth weight and gender. Journal of Clinical Endocrinology and Metabolism 199782 1642-1644.

59 Garcia-Mayor RV, Andrade MA, Rios M, Lage M, Dieguez C \& Casanueva FF. Serum leptin levels in normal children: relationship to age, gender, body mass index, pituitary-gonadal hormones and pubertal stage. Journal of Clinical Endocrinology and Metabolism 199782 2849-2855.

60 Blum WF, Englaro P, Hanitsch S, Juul A, Hertel NT, Müller J et al. Plasma leptin levels in healthy children and adolescents dependence on body mass index, body fat mass, gender, pubertal stage, and testosterone. Journal of Clinical Endocrinology and Metabolism 199782 2904-2910.

61 Falorni A, Bini V, Molinari D, Papi F, Celi F, Di Stefano G et al. Leptin serum levels in normal weight and obese children and adolescents: relationship with age, sex, pubertal development, body mass index, and insulin. International Journal of Obesity $199721881-890$.

62 Roemmich JN, Clark PA, Berr SS, Mai V, Mantzoros CS, Flier JS et al. Gender differences in leptin levels during puberty are related to the subcutaneous fat depot and sex steroids. American Journal of Physiology 1998275 E543-E551.

63 Wabitsch M, Blum WF, Muche R, Braun M, Hube F, Rascher W et al. Contribution of androgens to the gender difference in leptin production in obese children and adolescents. Journal of Clinical Investigation $1997100808-813$.

64 Lahlou N, Landais P, De Boissieu D \& Bougnères P-F. Circulating leptin in normal children and during the dynamic phase of juvenile obesity. Relation to body fatness, energy metabolism, caloric intake, and sexual dimorphism. Diabetes 199746989 993.

65 Casabiell X, Pineir V, Peino R, Lage M, Camina J, Gallego R et al. Gender differences in both spontaneous and stimulated leptin secretion by human omental adipose tissue in vitro: dexamethasone and estradiol stimulate leptin release in women, but not in men. Journal of Clinical Endocrinology and Metabolism 199883 2149-2155.

66 Sivan E, Whittaker P, Sinha D, Homko CJ, Lin M, Reece EA et al. Leptin in human pregnancy: the relationship with gestational hormones. American Journal of Obstetrics and Gynecology 1998 $1791128-1132$

67 Kristensen K, Pedersen SB \& Richelsen B. Regulation of leptin by steroid hormones in rat adipose tissue. Biochemical and Biophysical Research Communications 1999259 624-630.

68 Shimizu H, Shimomura Y, Nakanishi Y, Futawatari T, Ohtani K, Sato $\mathrm{N}$ et al. Estrogen increases in vivo leptin production in rats and human subjects. Journal of Endocrinology $1997154285-292$.

69 Mannucci E, Ognibene A, Becorpi A, Cremasco F, Pellegrini S, Ottanelli $\mathrm{S}$ et al. Relationship between leptin and oestrogens in healthy women. European Journal of Endocrinology 1998139 $198-201$.

70 Bützow TL, Moilanen JM, Lehtovirta M, Tuomi T, Hovatta O, Siegberg $\mathrm{R}$ et al. Serum and follicular fluid leptin during in vitro fertilization: relationship among leptin increase, body fat mass, and reduced ovarian response. Journal of Clinical Endocrinology and Metabolism 199984 3135-3139.

71 Wu-Peng S, Rosenbaum M, Nicolson M, Chua SC \& Leibel RL. Effects of exogenous gonadal steroids on leptin homeostasis in rats. Obesity Research 19997 586-592.

72 Hislop M, Ratanjee B, Soule S \& Marais A. Effects of anabolicandrogenic steroid use or gonadal testosterone suppression on serum leptin concentration in men. European Journal of Endocrinology 1999141 40-46.

73 Palmert MR, Radovick S \& Boepple PA. The impact of reversible gonadal sex steroid suppression on serum leptin concentrations in children with central precocious puberty. Journal of Clinical Endocrinology and Metabolism 199883 1091-1096.

74 Behre HM, Simoni M \& Nieschlag E. Strong association between serum levels of leptin and testosterone in men. Clinical Endocrinology 199747 237-240.

75 Jockenhövel F, Blum WF, Vogel E, Englaro P, Müller-Wieland D, Reinwein D et al. Testosterone substitution normalizes elevated serum leptin levels in hypogonadal men. Journal of Clinical Endocrinology and Metabolism 199782 2510-2513.

76 Elbers J. Asscheman H, Seidell J, Frolich M, Meinders A \& Gooren L. Reversal of the sex difference in serum leptin levels upon crosssex hormone administration in transsexuals. Journal of Clinical Endocrinology and Metabolism 199782 3267-3270.

77 Haffner SM, Miettinen H, Karhapää P, Mykkänen L \& Laakso M. Leptin concentrations, sex hormones, and cortisol in nondiabetic men. Journal of Clinical Endocrinology and Metabolism 199782 1807-1809.

78 Janssen J, Huizinga N, Stolk R, Grobbee D, Pols H, de Jong F et al. The acute effect of dexamethasone on plasma leptin concentrations and the relationships between fasting leptin, the IGF-I/ IGF-BP system, dehydroepiandrosterone, androstenedione and testosterone in an elderly population. Clinical Endocrinology $199848621-626$.

79 Apter D, Butzow TL, Laughlin GA \& Yen SS. Gonadotropinreleasing hormone pulse generator activity during pubertal transition in girls: pulsatile and diurnal patterns of circulating gonadotropins. Journal of Clinical Endocrinology and Metabolism $199376940-949$

80 Frisch RE \& McArthur JW. Menstrual cycles: fatness as a determinant of minimum weight for height necessary for their maintenance or onset. Science $1974185949-951$.

81 Hebebrand J, van der Heyden J, Devos R, Kopp W, Herpetz S, Remschmidt $\mathrm{H}$ et al. Plasma concentrations of obese protein in anorexia nervosa. Lancet 1995346 1624-1625.

82 Grinspoon S, Gulick T, Askari H, Landt M, Lee K, Anderson E et al. Serum leptin levels in women with anorexia nervosa. Journal of Clinical Endocrinology and Metabolism 199681 3861-3863.

83 Laughlin GA \& Yen SSC. Hypoleptinemia in women athletes: absence of a diurnal rhythm with amenorrhea. Journal of Clinical Endocrinology and Metabolism 199782 318-321. 
84 Yu W, Kimura M, Walczewska A, Karanth S \& McCann S. Role of leptin in hypothalamic-pituitary function. PNAS 199794 1023-1028.

85 McCann S, Kimura M, Walczewska A, Karanth S, Rettori V \& Yu W. Hypothalamic control of FSH and LH by FSH-RF, LHRH, cytokines, leptin and nitric oxide. Neuroimmunomodulation 1998 5 193-202.

86 Jin L, Burguera BG, Couce ME, Scheithauser BW, Lamsan J, Eberhardt NL et al. Leptin and leptin receptor expression in normal and neoplastic human pituitary: evidence of a regulatory role for leptin on pituitary cell proliferation. Journal of Clinical Endocrinology and Metabolism 199984 2903-2911.

87 Cioffi JA, Shafer AW, Zupancic TJ, Smith-Gbur J, Mikhail A, Platika D et al. Novel B219/OB receptor isoforms: possible role of leptin in hematopoiesis and reproduction. Nature Medicine 1996 2 585-588.

88 Cioffi J, Van Blerkom J, Antczak M, Shafer A, Wittmer S \& Snodgrass $\mathrm{H}$. The expression of leptin and its receptors in preovulatory human follicles. Molecular and Human Reproduction $19973467-472$.

89 Karlsson C, Lindell K, Svensson E, Bergh C, Lind P, Billig H et al. Expression of functional leptin receptors in the human ovary. Journal of Clinical Endocrinology and Metabolism 199782 41444148.

90 Zachow RJ \& Magoffin DA. Direct intraovarian effects of leptin: impairment of the synergistic action of insulin-like growth factor-I on follicle-stimulating hormone-dependent estradiol$17 \beta$ production by rat ovarian granulosa cells. Endocrinology 1997138 847-850.

91 Agarwal SK, Vogel K, Weitsman SR \& Magoffin DA. Leptin antagonizes the insulin-like growth factor-I augmentation of steroidogenesis in granulosa and theca cells of the human ovary. Journal of Clinical Endocrinology and Metabolism 1999841072 1076.

92 Spicer LJ \& Francisco CC. Adipose obese gene product, leptin, inhibits bovine ovarian thecal cell steroidogenesis. Biology of Reproduction 199858 207-212.

93 Barkan D, Jia H, Dantes A, Vardimon L, Amsterdam A, Rubinstein $\mathrm{M}$ et al. Leptin modulates the glucocorticoidinduced ovarian steroidogenesis. Endocrinology 1999140 1731-1738.

94 Chehab FF, Lim ME \& Lu R. Correction of the sterility defect in homozygous obese female mice by treatment with the human recombinant leptin. Nature Genetics 199612 318-320.

95 Mounzih K, Lu R \& Chehab FF. Leptin treatment rescues the sterility of genetically obese ob/ob males. Endocrinology 1997 138 1190-1193.

96 Barash IA, Cheung CC, Weigle DS, Ren H, Kabigting EB, Kuiper JL et al. Leptin is a metabolic signal to the reproductive system. Endocrinology 1996137 3144-3147.

97 Carro E, Pinilla L, Seoane LM, Considine RV, Aguilar E, Casanueva FF et al. Influence of endogenous leptin tone on the estrous cycle and luteinizing hormone pulsatility in female rats. Neuroendocrinology 199766 375-377.

98 Ahima RS, Prabakaran D \& Flier JS. Postnatal leptin surge and regulation of circadian rhythm of leptin by feeding; implications for energy homeostasis and neuroendocrine function. Journal of Clinical Investigation 1998101 1020-1027.

99 Ahima RS, Dushay J, Flier SN, Prabakaran D \& Flier JS. Leptin accelerates the onset of puberty in normal female mice. Journal of Clinical Investigation $199799391-395$.

100 Chehab FF, Mounzih K, Lu R \& Lim ME. Early onset of reproductive function in normal female mice treated with leptin. Science $199727588-90$.

101 Ahima RS, Prabakaran D, Mantzoros C, Ou D, Lowell B, Maratos-Flier $\mathrm{E}$ et al. Role of leptin in the neuroendocrine response to fasting. Nature 1996382 250-252.

102 Cheung CC, Thornton JE, Kuijper JL, Weigle DS, Clifton DK \& Steiner RA. Leptin is a metabolic gate for the onset of puberty in the female rat. Endocrinology 1997138 855-858.
103 Licinio J, Mantzoros C, Negrao AB, Cizza G, Wong M-L, Bongiono $\mathrm{PB}$ et al. Human leptin levels are pulsatile and inversely related to pituitary-adrenal function. Nature Medicine $19973575-579$.

104 Pombo M, Herrera-Justiniano E, Considine RV, Hermida RC, Galvez MJ, Martin T et al. Nocturnal rise of leptin in normal prepubertal and pubertal children and in patients with perinatal stalk-transection syndrome. Journal of Clinical Endocrinology and Metabolism 199782 2751-2754.

105 Støving RK, Vinten J, Handberg A, Ebbesen EN, Hangaard J, Hansen-Nord $M$ et al. Diurnal variation of the serum leptin concentration in patients with anorexia nervosa. Clinical Endocrinology 199848 761-768.

106 Mantzoros CS, Flier JS \& Rogol AD. A longitudinal assessment of hormonal and physical alterations during normal puberty in boys. V. Rising leptin levels may signal the onset of puberty. Journal of Clinical Endocrinology and Metabolism 199782 10661070 .

107 Quinton N, Smith R, Clayton P, Gill MS, Shalet S, Justice SK et al. Leptin binding activity changes with age: the link between leptin and puberty. Journal of Clinical Endocrinology and Metabolism $1999842336-2341$.

108 Hardie L, Trayhurn P, Abramovich D \& Fowler P. Circulating leptin in women: a longitudinal study in the menstrual cycle and during pregnancy. Clinical Endocrinology 199747 101-106.

109 Riad-Gabriel MG, Jinagouda SD, Sharma A, Boyadjian R \& Saad MF. Changes in plasma leptin during the menstrual cycle. European Journal of Endocrinology 1998139 528-531.

110 Paolisso G, Rizzo MR, Mazziotti G, Rotondi M, Tagliamonte MR, Varricchio $\mathrm{G}$ et al. Lack of association between changes in plasma leptin concentration and in food intake during the menstrual cycle. European Journal of Clinical Investigation 1999 29 490-495.

111 Cella F, Giordano G \& Cordera R. Serum leptin concentrations during the menstrual cycle in normal-weight women: effects of an oral triphasic estrogen-progestin medication. European Journal of Endocrinology 2000142 174-178.

112 Teirmaa T, Luukkaa V, Rouru J, Koulu M \& Huupponen R. Correlation between circulating leptin and luteinizing hormone during menstrual cycle in normal weight women. European Journal of Endocrinology 1998139 190-194.

113 Licinio J, Mantzoros C, Kaklamani W, Wong ML, Bongiorno PB, Mulla A et al. Synchronicity of frequently sampled, $24 \mathrm{~h}$ concentrations of circulating leptin, luteinizing hormone, and estradiol in healthy women. PNAS 199895 2541-2546.

114 Castracane VD, Kraemer RR, Franken MA, Kraemer GR \& Gimpel T. Serum leptin concentration in women: effect of age, obesity, and estrogen administration. Fertility and Sterility 1998 $70472-477$.

115 Butte N, Hopkinson J \& Nicholson M. Leptin in human reproduction: serum leptin levels in pregnant and lactating women. Journal of Clinical Endocrinology and Metabolism 199782 $585-589$

116 Schubring C, Kiess W, Englaro P, Rascher W, Dötsch J, Hanitsch S et al. Levels of leptin in maternal serum, amniotic fluid, and arterial and venous cord blood: relation to neonatal and placental weight. Journal of Clinical Endocrinology and Metabolism 199782 1480-1483.

117 Highman T, Friedman J, Huston L, Wong W \& Catalano P. Longitudinal changes in maternal serum leptin concentrations, body composition, and resting metabolic rate in pregnancy. American Journal of Obstetrics and Gynecology 1998178 10101015.

118 Stein TP, Scholl TO, Schluter MD \& Schroeder CM. Plasma leptin influences gestational weight gain and postpartum weight retention. American Journal of Clinical Nutrition $1998 \mathbf{6 8}$ $1236-1240$.

119 Tamas P, Sulyok E, Szabo I, Vizer M, Ertl T, Rascher W et al. Changes of maternal serum leptin levels during pregnancy. Gynecologic and Obstetric Investigation 199846 169-171. 
120 Tamura T, Goldenberg R, Johnston K \& Cliver S. Serum leptin concentrations during pregnancy and their relationship to fetal growth. Obstetrics and Gynecology 199891 389-395.

121 Lewandowski K, Horn R, O'Callaghan CJ, Dunlop D, Medley GF, O'Hare P et al. Free leptin, bound leptin, and soluble leptin receptor in normal and diabetic pregnancies. Journal of Clinical Endocrinology and Metabolism 199984 300-306.

122 Gavrilova O, Barr V, Marcus-Samuels B \& Reitman M. Hyperleptinemia of pregnancy is associated with the appearance of a circulating form of the leptin receptor. Journal of Biological Chemistry 1997272 30546-30551.

123 Masuzaki H, Ogawa Y, Sagawa N, Hosoda K, Matsumoto T, Mise $\mathrm{H}$ et al. Nonadipose tissue production of leptin: leptin as a novel placenta-derived hormone in humans. Nature Medicine 19973 1029-1033.

124 Hoggard N, Hunter L, Duncan J, Williams L, Trayhurn P \& Mercer J. Leptin and leptin receptor mRNA and protein expression in the murine fetus and placenta. PNAS 199794 11073-11078.

125 Brzechffa PR, Jakimiuk AJ, Agarwal SK, Weitsman SR, Buyalos RP \& Magoffin DA. Serum immunoreactive leptin concentrations in women with Polycystic Ovary Syndrome. Journal of Clinical Endocrinology and Metabolism 199681 4166-4169.

126 Vicennati V, Gambineri A, Calzoni F, Casimirri F, Macor C, Vettor $\mathrm{V}$ et al. Serum leptin in obese women with polycystic ovary syndrome is correlated with body weight and fat distribution but not with androgen and insulin levels. Metabolism 199847988 992

127 Micic D, Macut D, Popovic V, Sumarac-Dumanovic M, Kendereski A, Colic M et al. Leptin levels and insulin sensitivity in obese and non-obese patients with polycystic ovary syndrome. Gynecological Endocrinology 199711 315-320.

128 El Orabi H, Ghalia AA, Khalifa A, Mahfouz H, Shalkani AE \& Shoieb N. Serum leptin as an additional possible pathogenic factor in polycystic ovary syndrome. Clinical Biochemistry 1999 $3271-75$

129 Mantzoros CS, Dunaif A \& Flier JS. Leptin concentrations in the Polycystic Ovary Syndrome. Journal of Clinical Endocrinology and Metabolism 199782 1687-1691.

130 Laughlin G, Morales A \& Yen S. Serum leptin levels in women with polycystic ovary syndrome: the role of insulin resistance/ hyperinsulinemia. Journal of Clinical Endocrinology and Metabolism 199782 1692-1696.

131 Rouru J, Anttila L, Koskinen P, Penttilä T-A, Irjala K, Huupponen $\mathrm{R}$ et al. Serum leptin concentrations in women with Polycystic Ovary Syndrome. Journal of Clinical Endocrinology and Metabolism 199782 1697-1700.

132 Chapman IM, Wittert GA \& Norman RJ. Circulating leptin concentrations in polycystic ovary syndrome: relation to anthropometric and metabolic parameters. Clinical Endocrinology 199746 175-181.

133 Caro JF. Leptin is normal in PCOS - an editorial about three 'negative' papers. Journal of Clinical Endocrinology and Metabolism $1997821685-1686$

134 Haffner SM, Mykkänen L \& Stern MP. Leptin concentrations in women in the San Antonio Heart Study: effect of menopausal status and postmenopausal Hormone Replacement Therapy. American Journal of Epidemiology 1997146 581-585.

135 Sumner AE, Falkner B, Kushner H \& Considine RV. Relationship of leptin concentration to gender, menopause, age, diabetes, and fat mass in African Americans. Obesity Research $19986128-$ 133.

136 Kohrt WM, Landt M \& Birge SJ. Serum leptin levels are reduced in response to exercise training, but not hormone replacement therapy, in older women. Journal of Clinical Endocrinology and Metabolism 199681 3980-3985.

137 Baumgartner RN, Waters DL, Morley JE, Patrick P, Montoya GD \& Garry PJ. Age-related changes in sex hormones affect the sex difference in serum leptin independently of changes in body fat Metabolism 199948 378-384.
138 Ryan AS \& Elahi D. The effects of acute hyperglycemia and hyperinsulinemia on plasma leptin levels: its relationships with body fat, visceral adiposity, and age in women. Journal of Clinical Endocrinology and Metabolism 199681 4433-4438.

139 Schwartz MW, Prigeon RL, Kahn SE, Nicholson M, Moore J, Morawiecki A et al. Evidence that plasma leptin and insulin levels are associated with body adiposity via different mechanisms. Diabetes Care 199720 1476-1481.

140 Widjaja A, Stratton IM, Horn R, Holman RR, Turner R \& Brabant G. UKPDS 20: Plasma leptin, obesity, and plasma insulin in type 2 diabetic subjects. Journal of Clinical Endocrinology and Metabolism 199782 654-657.

141 Saladin R, De Vos P, Guerre-Millo M, Leturque A, Girard J, Staels B et al. Transient increase in obese gene expression after food intake or insulin administration. Nature $1995377527-$ 529.

142 Rentsch J \& Chiesi M. Regulation of ob gene mRNA levels in cultured adipocytes. FEBS Letters 1996379 55-59.

143 Kolaczynski JW, Nyce MR, Considine RV, Boden G, Nolan JJ, Henry $\mathrm{R}$ et al. Acute and chronic effect of insulin on leptin production in humans - studies in vivo and in vitro. Diabetes $199645699-701$.

144 Wabitsch M, Jensen PB, Blum WF, Christoffersen CT, Englaro P, Heinze E et al. Insulin and cortisol promote leptin production in cultured human fat cells. Diabetes 199645 1435-1438.

145 Hardie L, Guilhot N \& Trayhurn P. Regulation of leptin production in cultured mature white adipocytes. Hormone and Metabolic Research 199628 685-689.

146 MacDougald OA, Hwang C-S, Fan H \& Lane MD. Regulated expression of the obese gene product (leptin) in white adipose tissue and 3T3-L1 adipocytes. PNAS 199592 9034-9037.

147 Cusin I, Sainsbury A, Doyle P, Rohner-Jeanrenaud F \& Jeanrenaud B. The ob gene and insulin: a relationship leading to clues to the understanding of obesity. Diabetes $1995441467-$ 1470 .

148 Hardie LJ, Rayner DV, Holmes S \& Trayhurn P. Circulating leptin levels are modulated by fasting, cold exposure and insulin administration in lean but not Zucker ( $\mathrm{fa} / \mathrm{fa}$ ) rats as measured by ELISA. Biochemical and Biophysical Research Communications 1996223 660-665.

149 Patel B, Koenig J, Kaplan L \& Hooi S. Increase in plasma leptin and Lep mRNA concentrations by food intake is dependent on insulin. Metabolism 199847 603-607.

150 Sivitz WI, Walsh S, Morgan D, Donohoue P, Haynes W \& Leibel R. Plasma leptin in diabetic and insulin-treated diabetic and normal rats. Metabolism 199847 584-591.

151 Malmström R, Taskinen M-R, Karonen S-L \& Yki-Järvinen H. Insulin increases plasma leptin concentrations in normal subjects and patients with NIDDM. Diabetologia $199639993-$ 996.

152 Utriainen T, Malmström R, Mäkimattila S \& Yki-Järvinen $\mathrm{H}$. Supraphysiological hyperinsulinemia increases plasma leptin concentrations after $4 \mathrm{~h}$ in normal subjects. Diabetes 199645 1364-1366.

153 Boden G, Chen X, Kolaczynski J \& Polansky M. Effects of prolonged hyperinsulinemia on serum leptin in normal human subjects. Journal of Clinical Investigation 1997100 1107-1113.

154 Larsson H, Elmstahl S \& Ahrén B. Plasma leptin levels correlate to islet function independently of body fat in postmenopausal women. Diabetes $1996451580-1584$.

155 Vidal H, Auboeuf D, De Vos P, Staels B, Riou JP, Auwerx J et al. The expression of ob gene is not acutely regulated by insulin and fasting in human abdominal subcutaneous adipose tissue. Journal of Clinical Investigation 199698 251-255.

156 Nagasaka S, Ishikawa S, Nakamura T, Kawakami A, Rokkaku K, Hayashi $\mathrm{H}$ et al. Association of endogenous insulin secretion and mode of therapy with body fat and serum leptin levels in diabetic subjects. Metabolism 199847 1391-1396.

157 Korbonits M, Trainer PJ, Little JA, Edwards R, Kopelman PG, Besser GM et al. Leptin levels do not change acutely with food 
administration in normal or obese subjects, but are negatively correlated with pituitary-adrenal activity. Clinical Endocrinology $199746751-757$.

158 Muzzin P, Eisensmith RC, Copeland KC \& Woo SL. Correction of obesity and diabetes in genetically obese mice by leptin gene therapy. PNAS $19969314804-14808$.

159 Kulkarni RN, Wang Z-L, Wang R-M, Hurley JD, Smith DM, Ghatel MA et al. Leptin rapidly suppresses insulin release from insulinoma cells, rat and human islets and, in vivo, in mice. Journal of Clinical Investigation 1997100 2729-2736.

160 Harris RB. Acute and chronic effects of leptin on glucose utilization in lean mice. Biochemical and Biophysical Research Communications 1998245 502-509.

161 Sivitz WI, Walsh S, Morgan D, Thomas M \& Haynes W. Effects of leptin on insulin sensitivity in normal rats. Endocrinology 1997 $1383395-3401$.

162 Mizuno A, Murakami T, Otani S, Kuwajima M \& Shima K. Leptin affects pancreatic endocrine functions through the sympathetic nervous system. Endocrinology $19981393863-$ 3870

163 Considine RV \& Caro JF. Pleiotropic cellular effects of leptin. Current Opinion in Endocrinology and Diabetes 19996 163-169.

164 Kieffer TJ, Heller RS \& Habener JF. Leptin receptors expressed on pancreatic $\beta$-cells. Biochemical and Biophysical Research Communications $1996224522-527$.

165 Emilsson V, Liu Y-L, Cawthorne M, Morton NM \& Davenport M. Expression of the functional leptin receptor mRNA in pancreatic islets and direct inhibitory action of leptin on insulin secretion. Diabetes 199746 313-316.

166 Kieffer TJ, Heller RS, Leech CA, Holz GG \& Habener JF. Leptin suppression of insulin secretion by the activation of ATPsensitive $\mathrm{K}^{+}$channels in pancreatic $\beta$-cells. Diabetes 199746 1087-1093.

167 Chen N-G, Swick AG \& Romsos DR. Leptin constrains acetylcholine-induced insulin secretion from pancreatic islets of $o b / o b$ mice. Journal of Clinical Investigation 1997100 1174-1179.

168 Pallett AL, Morton NM, Cawthorne MA \& Emilsson V. Leptin inhibits insulin secretion and reduces insulin mRNA levels in rat isolated pancreatic islets. Biochemical and Biophysical Research Communications $1997238267-270$

169 Fehmann H-C, Peiser C, Bode H-P, Stamm M, Staats P, Hedetoft C et al. Leptin: a potent inhibitor of insulin secretion. Peptides 1997 18 1267-1273.

170 Ookuma M, Ookuma K \& York DA. Effects of leptin on insulin secretion from isolated rat pancreatic islets. Diabetes 199847 219-223.

171 Zhao AZ, Bornfeldt KE \& Beavo JA. Leptin inhibits insulin secretion by activation of phosphodiesterase 3B. Journal of Clinical Investigation 1998102 869-873.

172 Seufert J, Kieffer TJ, Leech CA, Holz GG, Moritz W, Ricordi C et al. Leptin suppression of insulin secretion and gene expression in human pancreatic islets: implications for the development of adipogenic diabetes mellitus. Journal of Clinical Endocrinology and Metabolism 199984 670-676.

173 Harvey J, McKenna F, Herson P, Spanswick D \& Ashford M. Leptin activates ATP-sensitive potassium channels in the rat insulin-secreting cell line, CRI-G1. Journal of Physiology 1997 $504527-535$.

174 Chen N-G \& Romsos DR. Persistently enhanced sensitivity of pancreatic islets from ob/ob mice to PKC-stimulated insulin secretion. American Journal of Physiology 1997272 E304-E311.

175 Poitout V, Rouault C, Guerre-Millo M, Briaud I \& Reach G. Inhibition of insulin secretion by leptin in normal rodent islets of Langerhans. Endocrinology $1998139822-826$.

176 Seufert J, Kieffer TJ \& Habener JF. Leptin inhibits insulin gene transcription and reverses hyperinsulinemia in leptin-deficient ob/ob mice. PNAS $199996674-679$.

177 Kamohara S, Burcelin R, Halaas JL, Friedman JM \& Charron MJ. Acute stimulation of glucose metabolism in mice by leptin treatment. Nature $1997389374-377$.
178 Koyama K, Chen G, Wang M-Y, Lee Y, Shimabukuro M, Newgard $\mathrm{CB}$ et al. $\beta$-cell function in normal rats made chronically hyperleptinemic by adenovirus-leptin gene therapy. Diabetes 199746 1276-1280.

179 Chinookoswong N, Wang J-L \& Shi Z-Q. Leptin restores euglycemia and normalizes glucose turnover in insulin-deficient diabetes in the rat. Diabetes 199948 1487-1492.

180 Barzilai N, She L, Liu L, Wang J, Hu M, Vuguin P et al. Decreased visceral adiposity accounts for leptin effect on hepatic but not peripheral insulin action. American Journal of Physiology 1999 277 E291-E298.

181 Schwartz MW, Baskin DG, Bukowski TR, Kuijper JL, Foster D, Lasser G et al. Specificity of leptin action on elevated blood glucose levels and hypothalamic Neuropeptide Y gene expression in ob/ob mice. Diabetes 199645 531-535.

182 Cohen B, Novick D \& Rubinstein M. Modulation of insulin activities by leptin. Science 1996274 1185-1188.

183 Rossetti L, Massillon D, Barzilai N, Vuguin P, Chen W, Hawkins M et al. Short term effects of leptin on hepatic gluconeogenesis and in vivo insulin action. Journal of Biological Chemistry 1997272 27758-27763.

184 Liu L, Karkanias GB, Morales JC, Hawkins M, Barzilai N, Wang J et al. Intracerebroventricular leptin regulates hepatic but not peripheral glucose fluxes. Journal of Biological Chemistry 1998 273 31160-31167.

185 Müller G, Ertl J, Gerl M \& Preibisch G. Leptin impairs metabolic actions of insulin in isolated rat adipocytes. Journal of Biological Chemistry 1997272 10585-10593.

186 Williams LB, Ohannesian DW, Kogon BE, Jones R, Inman M, Huse $\mathrm{J}$ et al. Leptin increases basal and insulin-stimulated glucose uptake into human subcutaneous adipocytes. Diabetes 199847 A73.

187 Fukuda H, Iritani N, Sugimoto T \& Ikeda H. Transcriptional regulation of fatty acid synthase gene by insulin/glucose, polyunsaturated fatty acid and leptin in hepatocytes and adipocytes in normal and genetically obese rats. European Journal of Biochemistry $1999260505-511$.

188 Berti L, Kellerer M, Capp E \& Häring H. Leptin stimulates glucose transport and glycogen synthesis in $\mathrm{C}_{2} \mathrm{C}_{12}$ myotubes: evidence for a PI3-kinase mediated effect. Diabetologia $199740606-609$.

189 Kellerer M, Koch M, Metzinger E, Mushack J, Capp E \& Häring H. Leptin activates PI-3 kinase in $\mathrm{C}_{2} \mathrm{C}_{12}$ myotubes via janus kinase2 (JAK-2) and insulin receptor substrate-2 (IRS-2) dependent pathways. Diabetologia $1997401358-1362$.

190 Ceddia R, William W \& Curi R. Comparing effects of leptin and insulin on glucose metabolism in skeletal muscle: evidence for an effect of leptin on glucose uptake and decarboxylation. International Journal of Obesity 199923 75-82.

191 Muoio DM, Dohm GL, Tapscott EB \& Coleman RA. Leptin opposes insulin's effects on fatty acid partitioning in muscles isolated from obese ob/ob mice. American Journal of Physiology 1999276 E913-E921.

192 Zierath JR, Frevert EU, Ryder JW, Berggren P-O \& Kahn BB. Evidence against a direct effect of leptin on glucose transport in skeletal muscle and adipocytes. Diabetes $1998471-4$.

193 Fürnsinn C, Brunmair B, Furtmüller R, Roden M, Englisch R \& Waldhäusl W. Failure of leptin to affect basal and insulinstimulated glucose metabolism of rat skeletal muscle in vitro. Diabetologia $199841524-529$.

194 Ranganathan S, Ciaraldi T, Henry R, Mudaliar S \& Kern P. Lack of effect of leptin on glucose transport, lipoprotein lipase, and insulin action in adipose and muscle cells. Endocrinology 1998 139 2509-2513.

195 Mick G, Vanderbloomer T, Fu CL \& McCormick K. Leptin does not affect adipocyte glucose metabolism: studies in fresh and cultured adipocytes. Metabolism 199847 1360-1365.

196 Burcelin R, Kamohara S, Li J, Tannenbaum GS, Charron MJ \& Friedman JM. Acute intravenous leptin infusion increases glucose turnover but not skeletal muscle glucose uptake in $\mathrm{ob} /$ ob mice. Diabetes 199948 1264-1269. 
197 Zimmet P \& Alberti K. Leptin: is it important in diabetes? Diabetic Medicine 199613 501-503.

198 Taylor SI, Barr V \& Reitman M. Does leptin contribute to diabetes caused by obesity? Science 1996274 1151-1152.

199 Shimabukuro M, Koyama K, Chen G, Wang M-Y, Trieu F, Lee Y et al. Direct antidiabetic effect of leptin through triglyceride depletion of tissues. PNAS 199794 4637-4641.

200 Sarmiento U, Benson B, Kaufman S, Ross L, Qi M, Scully S et al. Morphologic and molecular changes induced by recombinant human leptin in the white and brown adipose tissues of C57BL/6 mice. Laboratory Investigation 199777 $243-256$.

201 Haffner SM, Stern MP, Miettinen H, Wei M \& Gingerich RL. Leptin concentrations in diabetic and nondiabetic MexicanAmericans. Diabetes $199645822-824$.

202 McGregor GP, Desaga JF, Ehlenz K, Fischer A, Heese F, Hegele A et al. Radioimmunological measurement of leptin in plasma of obese and diabetic human subjects. Endocrinology 1996137 1501-1504.

203 De Courten M, Zimmet P, Hodge A, Collins V, Nicholson M, Staten $\mathrm{M}$ et al. Hyperleptinaemia: the missing link in the Metabolic Syndrome? Diabetic Medicine 199714 200-208.

204 Oppert J-M, Lahlou N, Laferrère B, Roger M, Basdevant A \& GuyGrand B. Plasma leptin and acute serotoninergic stimulation of the corticotropic axis in women who are normal weight or obese. Obesity Research 19975 410-416.

205 Pacak K, McCarty R, Palkovits M, Cizza G, Kopin IJ, Goldstein D et al. Decreased central and peripheral catecholaminergic activation in obese Zucker rats. Endocrinology 1995136 4360-4367.

206 Heiman ML, Ahima RS, Craft LS, Schoner B, Stephens TW \& Flier JS. Leptin inhibition of the hypothalamic-pituitaryadrenal axis in response to stress. Endocrinology 1997138 3859-3863.

207 Glasow A, Haidan A, Hilbers U, Breidert M, Gillespie J, Scherbaum WA et al. Expression of $\mathrm{Ob}$ receptor in normal human adrenals: differential regulation of adrenocortical and adrenomedullary function by leptin. Journal of Clinical Endocrinology and Metabolism 199883 4459-4466.

208 Takekoshi K, Motooka M, Isobe K, Nomura F, Manmoku T, Ishii $\mathrm{K}$ et al. Leptin directly stimulate catecholamine secretion and synthesis in cultured porcine adrenal medullary chromaffin cells. Biochemical and Biophysical Research Communications 1999 261 426-431.

209 Bornstein SR, Uhlmann K, Haidan A, Ehrhart-Bornstein M \& Scherbaum WA. Evidence for a novel peripheral action of leptin as a metabolic signal to the adrenal gland. Leptin inhibits cortisol release directly. Diabetes 199746 1235-1238.

210 Pralong F, Roduit R, Waeber G, Castillo E, Mosimann F, Thorens B et al. Leptin inhibits directly glucocorticoid secretion by normal human and rat adrenal gland. Endocrinology 19981394264 4268.

211 Kruse M, Bornstein S, Uhlmann K, Paeth G \& Scherbaum W. Leptin down-regulates the steroid producing system in the adrenal. Endocrine Research 199824 587-590.

212 Murakami T, Iida M \& Shima K. Dexamethasone regulates obese expression in isolated rat adipocytes. Biochemical and Biophysical Research Communications 1995214 1260-1267.

213 Slieker LJ, Sloop KW, Surface PL, Kriauciunas A, LaQuier F, Manetta J et al. Regulation of expression of $o b$ mRNA and protein by glucocorticoids and cAMP. Journal of Biological Chemistry $19962715301-5304$.

214 De Vos P, Saladin R, Auwerx J \& Staels B. Induction of ob gene expression by corticosteroids is accompanied by body weight loss and reduced food intake. Journal of Biological Chemistry 1995 270 15958-15961.

215 Zakrzewska KE, Cusin I, Stricker-Krongrad A, Boss O, Ricquier D, Jeanrenaud B et al. Induction of obesity and hyperleptinemia by central glucocorticoid infusion in the rat. Diabetes 199948 $365-370$.
216 Larsson H \& Ahren B. Short-term dexamethasone treatment increases plasma leptin independently of changes in insulin sensitivity in healthy women. Journal of Clinical Endocrinology and Metabolism $1996814428-4432$.

217 Berneis K, Vosmeer S \& Keller U. Effects of glucocorticoids and of growth hormone on serum leptin concentrations in man. European Journal of Endocrinology 1996135 663-665.

218 Miell J, Englaro P \& Blum W. Dexamethasone induces an acute and sustained rise in circulating leptin levels in normal human subjects. Hormone and Metabolic Research $199628704-$ 707.

219 Kiess W, Englaro P, Hanitsch S, Rascher W, Attanasio A \& Blum $W$. High leptin concentrations in serum of very obese children are further stimulated by dexamethasone. Hormone and Metabolic Research 199628 708-710.

220 Papaspyrou-Rao S, Schneider S, Petersen R \& Fried S. Dexamethasone increases leptin expression in humans in vivo. Journal of Clinical Endocrinology and Metabolism 199782 16351637.

221 Dagogo-Jack S, Selke G, Melson AK \& Newcomer JW. Robust leptin secretory responses to dexamethasone in obese subjects. Journal of Clinical Endocrinology and Metabolism 199782 32303233.

222 Kolaczynski JW, Goldstein BJ \& Considine RV. Dexamethasone, $\mathrm{OB}$ gene, and leptin in humans; effect of exogenous hyperinsulinemia. Journal of Clinical Endocrinology and Metabolism 199782 3895-3897.

223 Ur E, Grossman A \& Després J. Obesity results as a consequence of glucocorticoid induced leptin resistance. Hormone and Metabolic Research 199628 744-747.

224 Leal-Cerro A, Considine R, Peino R, Venegas E, Astorga R, Casanueva FF et al. Serum immunoreactive leptin levels are increased in patients with Cushing's syndrome. Hormone and Metabolic Research 199628 711-713.

225 Masuzaki H. Ogawa Y \& Hosoda K. Glucocorticoid regulation of leptin synthesis and secretion in humans: elevated plasma leptin levels in Cushing's syndrome. Journal of Clinical Endocrinology and Metabolism 199782 2542-2547.

226 Widjaja A, Schurmeyer TH, Von zur Muhlen A \& Brabant G. Determinants of serum leptin levels in Cushing's syndrome. Journal of Clinical Endocrinology and Metabolism 199883 600603.

227 Zakrzewska KE, Cusin I, Sainsbury A, Rohner-Jeanrenaud F \& Jeanrenaud B. Glucocorticoids as counterregulatory hormones of leptin. Towards an understanding of leptin resistance. Diabetes $199746717-719$.

228 Toni R, Jackson IM \& Lechan RM. Neuropeptide-Y-immunoreactive innervation of thyrotropin-releasing hormone-synthesizing neuron in the rat hypothalamic paraventricular nucleus. Endocrinology $19901262444-2453$.

229 Hisano S, Fukui Y, Chikamori-Aoyama M, Aizawa T \& Shibasaki T. Reciprocal synaptic relations between CRF-immunoreactive and TRH-immunoreactive neurons in the paraventricular nucleus of the rat hypothalamus. Brain Research 1993620 343-346.

230 Legradi G, Emerson C, Ahima R, Flier J \& Lechan R. Leptin prevents fasting-induced suppression of prothyrotropin-releasing hormone messenger ribonucleic acid in neurons of the hypothalamic paraventricular nucleus. Endocrinology 1997138 2569-2576.

231 Fain J, Coronel E, Beauchamp M \& Bahouth S. Expression of leptin and beta 3-adrenergic receptors in rat adipose tissue in altered thyroid states. Biochemical Journal 1997322 145-150.

232 Escobar-Morreale HF, Escobar del Rey F \& Morreale de Escobar G. Thyroid hormones influence serum leptin concentrations in the rat. Endocrinology 1997138 4485-4488.

233 Yoshida T, Monkawa T, Hayashi M \& Saruta T. Regulation of expression of leptin mRNA and secretion of leptin by thyroid hormone in 3T3-L1 adipocytes. Biochemical and Biophysical Research Communications 1997232 822-826. 
234 Mantzoros C, Rosen H, Greenspan S, Flier J \& Moses A. Short-term hyperthyroidism has no effect on leptin levels in man. Journal of Clinical Endocrinology and Metabolism 199782 497-499.

235 Ozata M, Ozisik G, Bingol N, Corakci A \& Gundogan M. The effects of thyroid status on plasma leptin levels in women. Journal of Endocrinological Investigation 199821 337-341.

236 Pinkney JH, Goodrick SJ, Katz J, Johnson AB, Lightman SC, Coppack SW et al. Leptin and the pituitary-thyroid axis: a comparative study in lean, obese, hypothyroid and hyperthyroid subjects. Clinical Endocrinology 199849 583-588.

237 Valcavi R, Zini M, Peino R, Casanueva F \& Dieguez C. Influence of thyroid status on serum immunoreactive leptin levels. Journal of Clinical Endocrinology and Metabolism 199782 1632-1634.

238 Yoshida T, Momotani N, Hayashi M, Monkawa T, Ito K \& Saruta T. Serum leptin concentrations in patients with thyroid disorders. Clinical Endocrinology 199848 299-302.

239 Leonhardt U, Ritzel U, Schafer G, Becker W \& Ramadori G. Serum leptin levels in hypo- and hyperthyroidism. Journal of Endocrinology 1998157 75-79.

240 Zimmermann-Belsing T, Dreyer M, Holst JJ \& Feldt-Rasmussen U. The relationship between the serum leptin concentrations of thyrotoxic patients during treatment and their total fat mass is different from that of normal subjects. Clinical Endocrinology $199849589-595$.

241 Sreenan S, Caro JF \& Refetoff S. Thyroid dysfunction is not associated with alterations in serum leptin levels. Thyroid 1997 7 407-409.

242 Corbetta S, Englaro P, Giambona S, Persani L, Blum W \& BeckPeccoz P. Lack of effects of circulating thyroid hormone levels on serum leptin concentrations. European Journal of Endocrinology $1997137659-663$.

243 Sesmilo G, Casamitjana R, Halperin I, Gomis R \& Vilardell E. Role of thyroid hormones on serum leptin levels. European Journal of Endocrinology $1998139428-430$.

244 Scacchi M, Pincelli A \& Cavagnini F. Growth hormone in obesity. International Journal of Obesity 199923 260-271.

245 Hartman ML, Veldhuis JD, Johnson ML, Lee MM, Alberti KG, Samojlik E et al. Augmented growth hormone (GH) secretory burst frequency and amplitude mediate enhanced GH secretion during a two-day fast in normal men. Journal of Clinical Endocrinology and Metabolism 199274 757-765.

246 De Boer H, Blok G-J \& van der Veen EA. Clinical aspects of growth hormone deficiency in adults. Endocrine Reviews 19951663 86.

247 Madej T, Boguski MS \& Bryant SH. Threading analysis suggest that the obese gene product may be a helical cytokine. FEBS Letters 1995373 13-18.

248 Tannenbaum GS, Gurd W \& Lapointe M. Leptin is a potent stimulator of spontaneous pulsatile growth hormone $(\mathrm{GH})$ secretion and the $\mathrm{GH}$ response to GH-releasing hormone. Endocrinology 1998139 3871-3875.

249 Quintela M, Senaris R, Heiman M, Casanueva F \& Dieguez C. Leptin inhibits in vitro hypothalamic somatostatin secretion and somatostatin mRNA levels. Endocrinology 1997138 56415644.

250 Shimon I, Yan X, Magoffin DA, Friedman TC \& Melmed S. Intact leptin receptor is selectively expressed in human fetal pituitary and pituitary adenomas and signals human fetal pituitary growth hormone secretion. Journal of Clinical Endocrinology and Metabolism 199883 4059-4064.

251 Roh S-G, Clarke IJ, Xu R-W, Goding JW, Loneragan K \& Chen C. The in vitro effect of leptin on basal and growth hormonereleasing hormone-stimulated growth hormone secretion from the ovine pituitary gland. Neuroendocrinology 199868361 364.

252 Cai A \& Hyde JF. Upregulation of leptin receptor gene expression in the anterior pituitary of human growth hormone-releasing hormone transgenic mice. Endocrinology $1998139420-423$.

253 LaPaglia N, Steiner J, Kirsteins L, Emanuele M \& Emanuele N. Leptin alters the response of the growth hormone releasing factor-growth hormone-insulin-like growth factor-I axis to fasting. Journal of Endocrinology 1998159 79-83.

254 Cocchi D, De Gennaro-Colonna V, Bagnasco M, Bonacci D \& Muller EE. Leptin regulates GH secretion in the rat by acting on GHRH and somatostatinergic functions. Journal of Endocrinology $199916295-99$.

255 Carro E, Senaris R, Considine R, Casanueva F \& Dieguez C. Regulation of in vivo growth hormone secretion by leptin. Endocrinology 1997138 2203-2206.

256 Carro E, Seoane L, Senaris R, Casanueva F \& Dieguez C. Leptin increases in vivo $\mathrm{GH}$ responses to GHRH and GHRP-6 in fooddeprived rats. European Journal of Endocrinology $200014266-$ 70 .

257 Gill M, Toogood A, O’Neill P, Thorner M, Shalet S \& Clayton P. Relationship between growth hormone $(\mathrm{GH})$ status, serum leptin and body composition in healthy and $\mathrm{GH}$ deficient elderly subjects. Clinical Endocrinology 199747 161-167.

258 Coutant R, Lahlou N, Bouvattier C \& Bougnères P. Circulating leptin level and growth hormone response to stimulation tests in obese and normal children. European Journal of Endocrinology $1998139591-597$.

259 Roubenoff R, Rall LC, Veldhuis JD, Kehayias JJ, Rosen C, Nicholson $\mathrm{M}$ et al. The relationship between growth hormone kinetics and sarcopenia in postmenopausal women: the role of fat mass and leptin. Journal of Clinical Endocrinology and Metabolism 199883 1502-1506.

260 Manglik S, Cobanov B, Flores G, Nadjafi R \& Tayek JA. Serum insulin but not leptin is associated with spontaneous and growth hormone (GH)-releasing hormone-stimulated $\mathrm{GH}$ secretion in normal volunteers with and without weight loss. Metabolism 199847 1127-1133.

261 Böni-Schnetzler M, Hauri C \& Zapf J. Leptin is suppressed during infusion of recombinant human insulin-like growth factor I (rhIGF-I) in normal rats. Diabetologia 199942 160-166.

262 Dagogo-Jack S, Franklin S, Vijayan A, Liu J, Askari H, Miller SB et al. Recombinant human insulin-like growth factor-I (IGF-I) therapy decreases plasma leptin concentration in patients with chronic renal insufficiency. International Journal of Obesity 1998 22 1110-1115.

263 Wolthers T, Grofte T, Norrelund H, Poulsen PL, Andreasen F, Christiansen JS et al. Differential effects of growth hormone and prednisolone on energy metabolism and leptin levels in humans. Metabolism $19984783-88$.

264 Kristensen K, Pedersen SB, Fisker S, Norrelund H, Rosenfalck AM, Jorgensen JOL et al. Serum leptin levels and leptin expression in growth hormone $(\mathrm{GH})$-deficient and healthy adults: influence of $\mathrm{GH}$ treatment, gender, and fasting. Metabolism 199847 1524-1519.

265 Karlsson C, Stenlöf K, Johansson G, Marin P, Björntorp P, Bengtsson B-A et al. Effects of growth hormone treatment on the leptin system and on energy expenditure in abdominally obese men. European Journal of Endocrinology 1998138 408414.

266 Donahoo WT, Jensen DR, Yost TJ \& Eckel RH. Isoproterenol and somatostatin decrease plasma leptin in humans: a novel mechanism regulating leptin secretion. Journal of Clinical Endocrinology and Metabolism 199782 4139-4143.

267 Fisker S, Vahl N, Hansen T, Jorgensen JOL, Hagen C, Orskov H et al. Serum leptin is increased in growth hormone-deficient adults: relationship to body composition and effects of placebocontrolled growth hormone therapy for 1 year. Metabolism 1997 $46812-817$.

268 Al-Shoumer K, Anyaoku V, Richmond W \& Johnston D. Elevated leptin concentrations in growth hormone-deficient hypopituitary adults. Clinical Endocrinology 199747 153-159.

269 Nyström F, Ekman B, Österlund M, Lindström T, Öhman K \& Arnqvist H. Serum leptin concentrations in a normal population and in $\mathrm{GH}$ deficiency: negative correlation with testosterone in men and effects of GH treatment. Clinical Endocrinology 199747 191-198 
270 Nørrelund H, Gravholt CH, Englaro P, Blum WF, Rascher W, Christiansen JS et al. Increased levels but preserved diurnal variation of serum leptin in GH-deficient patients: lack of impact of different modes of $\mathrm{GH}$ administration. European Journal of Endocrinology $1998138644-652$.

271 Kousta E, Chrisoulidou A, Lawrence NJ, Al-Shoumer KAS, Parker KH, McCarthy MI et al. The circadian rhythm of leptin is preserved in growth hormone deficient hypopituitary adults. Clinical Endocrinology 199848 685-690.

272 De Boer H, Blok G-J, Voerman B, Derriks P \& van der Veen E. Changes in subcutaneous and visceral fat mass during growth hormone replacement therapy in adult men. International Journal of Obesity 199620 580-587.
273 Florkowski C, Collier G, Zimmet P, Livesey JH, Espiner EA \& Donald RA. Low-dose growth hormone replacement lowers plasma leptin and fat stores without affecting body mass index in adults with growth hormone deficiency. Clinical Endocrinology $199645769-773$

274 Janssen Y, Frölich M, Deurenberg P \& Roelfsema F. Serum leptin levels during recombinant human $\mathrm{GH}$ therapy in adults with $\mathrm{GH}$ deficiency. European Journal of Endocrinology 1997137 650654 .

Received 8 March 2000

Accepted 22 May 2000 